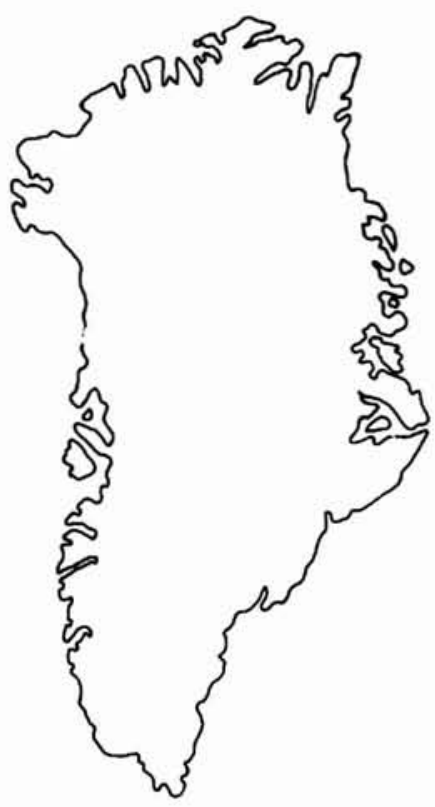

\title{
Proterozoic basins of North Greenland
}

\author{
Martin Sønderholm and Hans F. Jepsen
}

\begin{abstract}
Three major phases of sedimentary basin evolution can be recognised in the Proterozoic geological record of North Greenland. The earliest sedimentary basin phase is witnessed by the Middle Proterozoic Independence Fjord Group, a more than $2000 \mathrm{~m}$ thick sandstone-dominated succession consisting of intracratonic, mainly ephemeral stream and probable aeolian deposits with thin, but widespread intervals of lacustrine sedimentation. These deposits were intruded around $1230 \mathrm{Ma}$ by doleritic sills and dykes and overlain by associated basalts forming the second evolutionary phase. The basalts are at least $1350 \mathrm{~m}$ thick with a minimum extent of $10000 \mathrm{~km}^{2}$. This major volcanic phase can be traced from Arctic Canada to North-East Greenland and probably represents a period of rifting and continental break-up related to the opening of a pre-Grenvillian ocean.

After a period of at least $400 \mathrm{Ma}$ with no preserved geological record, a Late Proterozoic sedimentary phase occurred. This is represented by the Morænes $\emptyset$ Formation and the Hagen Fjord Group which occur in geographically separated areas with no proven correlation between them. The Morænesø Formation mainly consists of diamictites and sandstones forming valley-fill deposits in up to $200 \mathrm{~m}$ thick successions, recording Varangian deglaciation processes. The Hagen Fjord Group comprises up to $1000 \mathrm{~m}$ of siliciclastic and carbonate deposits of mainly shallow water shelf origin. Partly correlative deep water deposits referred to the approximately 2500 $\mathrm{m}$ thick Rivieradal sandstones are found in Caledonian nappe structures in Kronprins Christian Land.

The Proterozoic basins in central and eastern North Greenland are separated from the deposits of the Franklinian Basin (Cambrian-Silurian) by an extremely flat unconformity marking a hiatus of $10-30 \mathrm{Ma}$.
\end{abstract}

M. S. \& H. F. J., Geological Survey of Greenland, Øster Voldgade 10, DK-1350 Copenhagen K, Denmark.

Proterozoic sedimentary and associated igneous rocks along the margin of the Precambrian crystalline shield in North Greenland (Fig. 1) have been studied by several geological field-teams since 1912 when they were first investigated during the First Thule Expedition. Pioneering work was carried out by Lauge Koch, first as a member of the Second Thule Expedition (1916-1918) and later as leader of the Danish Jubilee Expedition (1920-1923), resulting in a description of the geology of the area between the Thule district and Peary Land (Koch, 1920, 1925, 1929, 1933). Later, during the Danish Thule and Ellesmere Land Expedition 1939-41, information on the Proterozoic and Lower Palaeozoic sedimentary successions of the regions around Kane Basin and Kennedy Channel was collected by Troelsen (1950). Proterozoic and Lower Palaeozoic successions in Peary Land were studied by members of the Danish Peary Land Expeditions 1948-50 and 1963-68 (Troelsen, 1949, 1956; Ellitsgaard-Rasmussen, 1950; Jepsen,
1971). During the Danish Expeditions to East Greenland 1947-58, Adams \& Cowie (1953) and Fränkl (1954, 1955) examined Proterozoic and Lower Palaeozoic sedimentary successions in the Kronprins Christian Land area; systematic aerial reconnaissance was carried out by Haller (e.g. 1971, 1983) in eastern North Greenland. This earlier work has been reviewed by Dawes (1971, 1976), Dawes \& Christie (1982) and Christie \& Dawes (in press).

More recently, the Proterozoic strata of North Greenland have been studied in greater detail by the Geological Survey of Greenland (GGU) during the North Greenland Project of 1978-80 and 1983-85 (e.g. Peel et al., 1982; Collinson, 1983; Kalsbeek \& Jepsen, 1983, 1984; Hurst et al., 1985; Collinson et al., 1989; Clemmensen \& Jepsen, in press). The present paper reviews these studies in an attempt to elucidate the development of the sedimentary basins in North Greenland during the Proterozoic. 


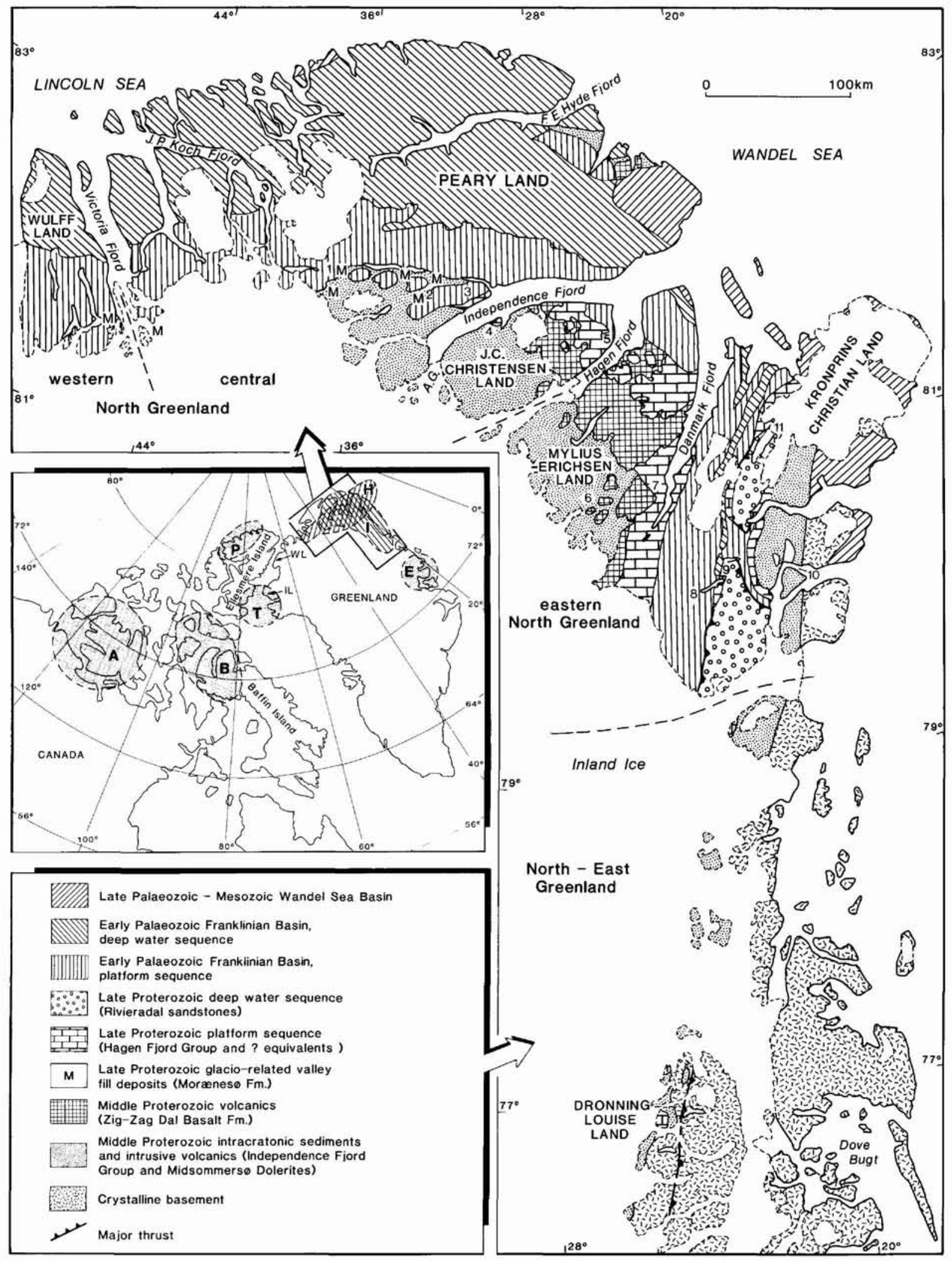




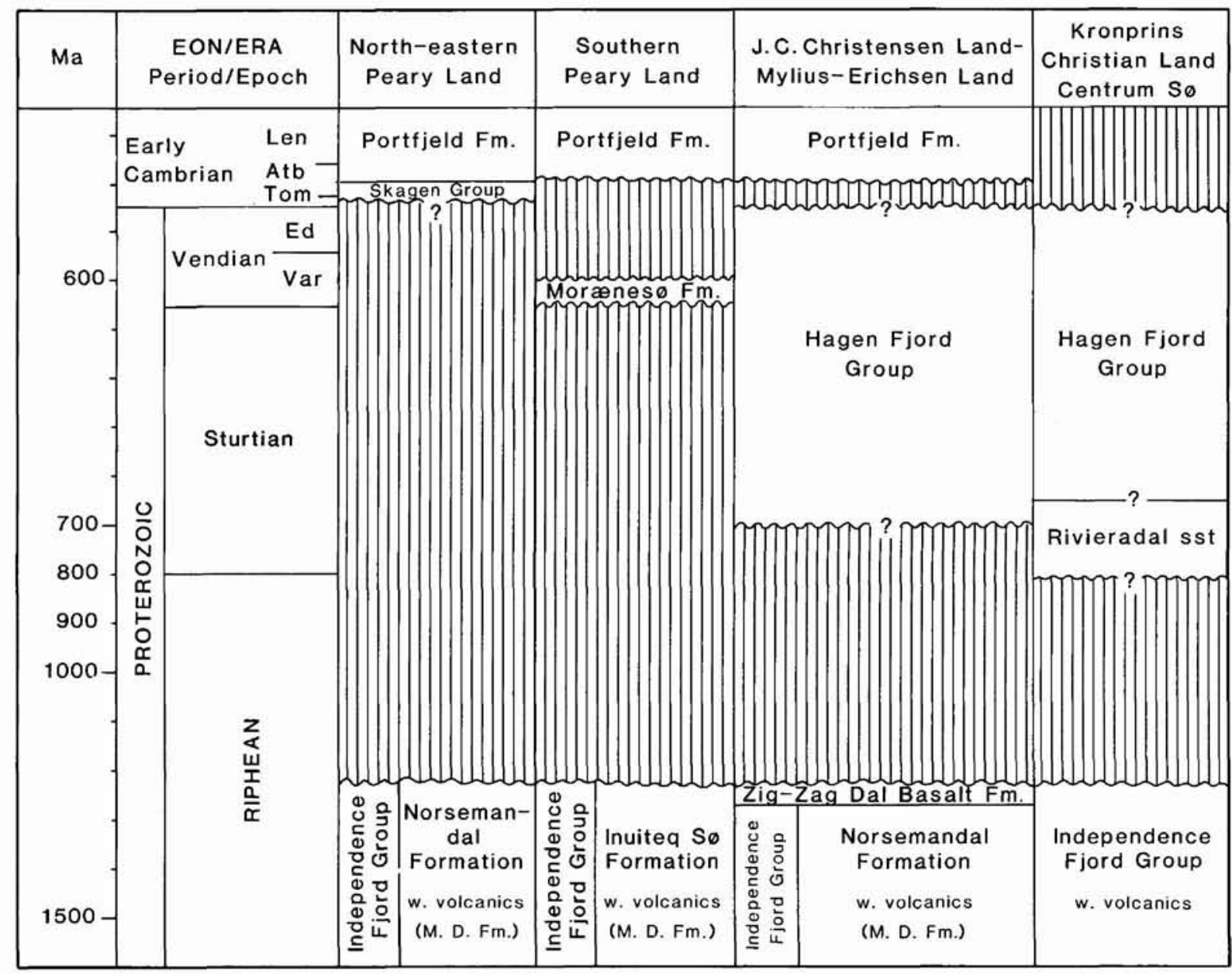

Fig. 2. Stratigraphy of the Proterozoic basins in North Greenland. M. D. Fm., Midsommersø Dolerite Formation. Atb, Atdabanian; Ed, Ediacaran; Len, Lenian; Tom, Tommotian; Var, Varangian. Time scale adapted from Harland et al. (1989).

\section{Geological framework}

Crystalline basement rocks of the Greenland Shield are exposed beneath Proterozoic and younger sedimentary strata in several areas in the northern part of Greenland (Fig. 1). In Inglefield Land, North-West Greenland, crystalline rocks of Proterozoic age are overlain by a succession of Proterozoic and Cambrian sediments (Peel et al., 1982; Dawes, 1988; Dawes et al., 1988). In southern Wulff Land, and on the nunataks at the head of Victoria Fjord (Fig. 1), Archaean gneisses are overlain by Upper Proterozoic sediments (Hansen $e t$ al., 1987). In eastern North Greenland, crystalline basement rocks are exposed in the fjord region along the

Fig. 1. Simplified geological map of North and North-East Greenland showing the outcrops of Proterozoic basins and main structural elements in Kronprins Christian Land. 1, Sydpasset; 2, Morænes $ø$; 3, Heilprin Land/Catalinafjeld; 4, Astrup Fjord; 5 , Kap Bernhard; 6, Norsemandal; 7, Kap Holbæk; 8, Centrum Sø; 9, Sæfaxi Elv; 10, Hekla Sund; 11, Romer Sø. Insert map shows the occurrence of other Proterozoic basins in adjoining areas. A: Amundsen Embayment (Late Proterozoic; Young, 1981); B: Borden Basin (Middle to ?Late Proterozoic; Jackson \& Ianelli, 1981; Fahrig et al., 1981; Stewart, 1987); E: Eleonore Bay Group and Tillite Group basins (Late Proterozoic; Haller, 1971; Hambrey \& Spencer, 1987; Caby \& Bertrand-Sarfati, 1988; Sønderholm et al., 1989; Sønderholm \& Tirsgaard, 1990); H: Hagen Fjord Basin and Morænes $\emptyset$ Formation (Late Proterozoic); I: Independence Fjord Basin (Middle Proterozoic); P: Pearya basin (?Late Proterozic possibly exotic terrane; Trettin, 1987); T: Thule Basin (Middle to Late Proterozoic; Dawes et al., 1982; Dawes \& Vidal, 1985; Dawes \& Rex, 1986); IL: Inglefield Land; WL: Washington Land. Maps adapted from Clemmensen \& Jepsen (in press). 


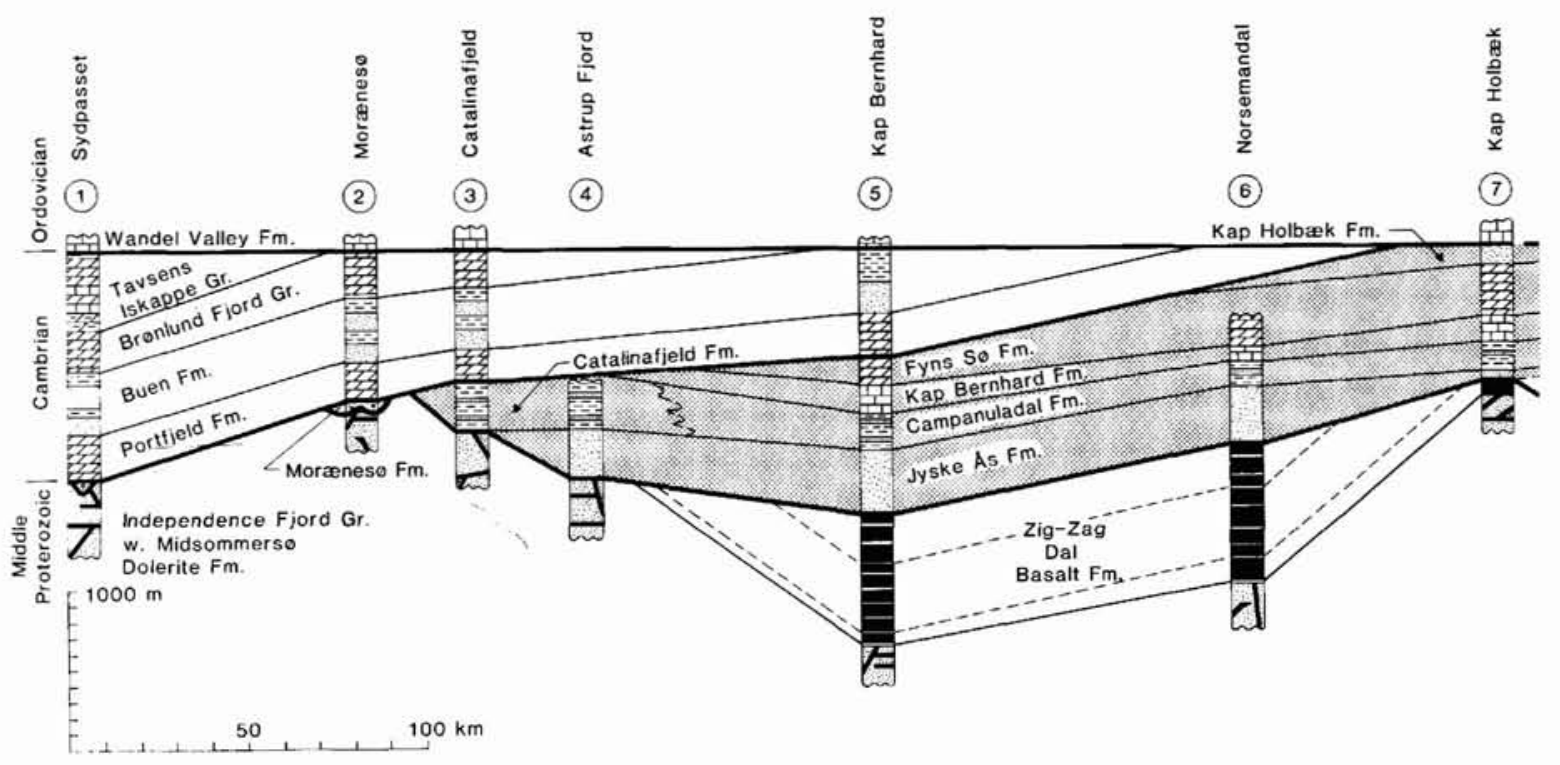

east coast of Kronprins Christian Land, as well as further south in North-East Greenland.

In central and eastern North Greenland and in NorthEast Greenland the crystalline basement is unconformably overlain by Middle Proterozoic, non-marine siliciclastic sediments (Fig. 2). These sediments are referred to the Independence Fjord Group (Collinson, 1980), and to the Trekant 'series' (Peacock, 1956; Friderichsen et al., 1990). Coeval sediments are found in the Thule Basin of northern Baffin Bay (Fig. 1; Dawes et al., 1982; Dawes \& Vidal, 1985; Dawes \& Rex, 1986; P. R. Dawes, personal communication, 1990). Intrusive igneous rocks are conspicuous in both successions. In Inglefield Land on the northern margin of the Thule Basin (Fig. 1) they give $\mathrm{K} / \mathrm{Ar}$ isotopic ages of $1190-1070 \mathrm{Ma}$ (Dawes et al., 1973) and in eastern North Greenland $\mathrm{Rb} / \mathrm{Sr}$ isotope analyses of the Midsommers $\varnothing$ Dolerite Formation yield ages of about $1230 \mathrm{Ma}$ (Kalsbeek \& Jepsen, 1983, 1984). This volcanism probably represents a period of rifting connected with the initial opening of an ocean along the northern margin of the Canadian-Greenland Shield (Jackson \& Ianelli, 1981).

The upper boundary of these Middle Proterozoic intracratonic sediments and volcanics in central and eastern North Greenland is an erosional unconformity of regional extent upon which Late Proterozoic sediments rest. In the western part of the region the glacio-related Morænes $\emptyset$ Formation was deposited while to the east the shallow-marine Hagen Fjord Group, with the partly equivalent deep-water Rivieradal sandstones, was deposited as a westwards transgressive sequence at the margin of the Iapetus Ocean (Hurst \& McKerrow,
1985; Clemmensen \& Jepsen, in press). In the intervening time interval of at least $400 \mathrm{Ma}$ no geologic record is preserved in North Greenland (Fig. 2, see also Fig. 18). However, information from northern Ellesmere Island, Canada, suggests that plate collision took place during Grenvillian time (1100-1000 Ma) along the northern margin of the Canadian-Greenland Shield, resulting in intense deformation, amphibolite-grade metamorphism and intrusion of granitic plutons (Trettin, 1987). Although no obvious traces of this Grenvillian orogenesis are known from North Greenland (Jepsen \& Kalsbeek, 1985), it may have been responsible in part for the period of uplift and erosion prior to the deposition of the Hagen Fjord Group.

Towards the end of the Proterozoic a period of significant uplift, block-faulting and erosion affected the area between southern Peary Land and J. C. Christensen Land (Fig. 2, see also Fig. 18). This uplift and erosion may be related to the initial phases of rifting during the opening of the Franklinian Basin. However, no signs of volcanic activity related to this opening have been observed in North Greenland.

During the Early Cambrian, the Franklinian sea transgressed the peneplained top of the Proterozoic shelf sequence of central and eastern North Greenland (Figs 2, 3, see also Fig. 18), resulting in north to south onlap by the mainly siliciclastic Lower Cambrian Skagen Group and the overlying platform carbonates of the Portfjeld Formation (Higgins et al., 1991).

Regional uplift of the platform area in eastern North Greenland during the Cambrian and Early Ordovician, which was probably caused by early Caledonian tectonic 
(8)
Fig. 3. Schematic cross-section of the Hagen Fjord Group from Sydpasset in the north-west to Centrum $\oint \emptyset$ in the south-east. Locality numbers refer to Fig. 1. Adapted from Clemmensen \& Jepsen (in press).

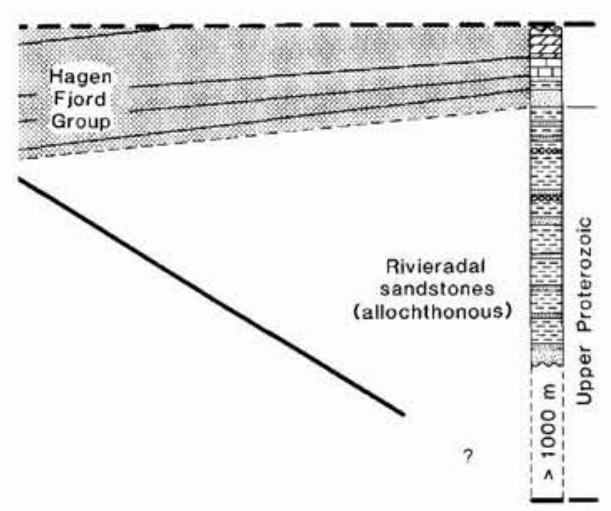

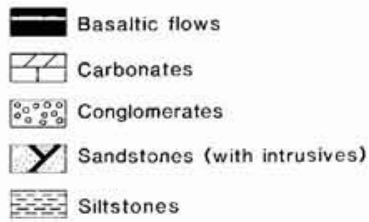

Bold lines represent erosional unconformities activity, resulted in an overstepping of the Early-Middle Ordovician Wandel Valley Formation from Cambrian strata onto the Hagen Fjord Group in Kronprins Christian Land (Fig. 3, see also Fig. 18) (Higgins et al., 1991).

Along the eastern coast of North Greenland, late Silurian Caledonian deformation resulted in westward transport of large nappe structures. The nappes are partly composed of strata belonging to the Rivieradal sandstones and to the Hagen Fjord Group. These allochthonous sediments may have been deposited east of the present-day coastline (Hurst \& McKerrow, 1985).

\section{Lithostratigraphy and basin evolution}

Three major phases of basin evolution are recognised within the Proterozoic of North Greenland.

1. Middle Proterozoic intracratonic sag sedimentation (Independence Fjord Group).

2. Middle Proterozoic continental rifting and volcanic activity (Midsommers $\emptyset$ Dolerite and Zig-Zag Dal Basalt Formation), followed by a more than $400 \mathrm{Ma}$ long period without any preserved geological record.

3. Late Proterozoic sedimentation, represented by the glacially influenced Morænes $\emptyset$ Formation and the shelf and trough sediments of the Hagen Fjord Group and Rivieradal sandstones.

These three phases are described in ascending order below. Stratigraphic relationships between the Morænes $\emptyset$ Formation and the Hagen Fjord Group are uncertain since the two units occur in separate areas.
Hence, the units are described separately below, while problems associated with their correlation are discussed at the end of the paper.

\section{Middle Proterozoic intracratonic sag sedimentation}

The oldest sedimentary basin phase in North Greenland is represented by the more than $2 \mathrm{~km}$ thick succession of mainly clastic alluvial deposits referred to the Independence Fjord Group (Collinson, 1980). Outcrops of the group and the correlative 'Trekant series' of Dronning Louise Land in North-East Greenland (Peacock, 1956) occur in a $400 \mathrm{~km}$ long belt stretching from the south side of Frederick E. Hyde Fjord in northeastern Peary Land to the northern part of Dronning Louise Land (Fig. 1; Christie \& Ineson, 1979; Collinson, 1980; Hurst et al., 1985; Friderichsen et al., 1990).

Radiometric data $(\mathrm{Rb} / \mathrm{Sr})$ have yielded ages around $1380 \mathrm{Ma}$ for clays within the middle part of the group (Larsen \& Graff-Petersen, 1980), and $1230 \pm 25 \mathrm{Ma}$ for dolerite and granophyre intrusions (Jepsen \& Kalsbeek, 1979), indicating a Middle Proterozoic age.

The base of the Independence Fjord Group is hidden beneath the Inland Ice, but the group is inferred to lie unconformably upon crystalline basement. Strata assigned to the group are conformably overlain by an up to $1350 \mathrm{~m}$ thick succession of extrusive basalts (the Zig-Zag Dal Basalt Formation of Jepsen \& Kalsbeek, 1979) in the area between Independence Fjord and Danmark Fjord, but to the north-west of Independence Fjord the group is unconformably overlain by Upper 


\begin{tabular}{|c|c|c|c|}
\hline \multicolumn{4}{|c|}{ Independence Fjord Group } \\
\hline \multicolumn{2}{|r|}{ Heilprin Land } & \multicolumn{2}{|c|}{$\begin{array}{l}\text { J.C. Christensen Land } \\
\& \\
\text { Mylius-Erichsen Land }\end{array}$} \\
\hline \multirow{5}{*}{ 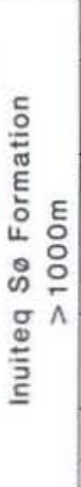 } & \multirow{3}{*}{ 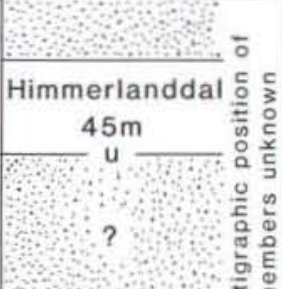 } & \multirow{5}{*}{ 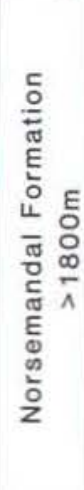 } & $\begin{array}{l}\text { Fiil Fjord } \\
(465-600 \mathrm{~m})\end{array}$ \\
\hline & & & $\begin{array}{l}\text { Kap Stadil } \\
(65-90 \mathrm{~m})\end{array}$ \\
\hline & & & $\begin{array}{l}\text { Astrup Fjord } \\
(290 \mathrm{~m})\end{array}$ \\
\hline & Baggárden tis & & $\begin{array}{c}\text { Hagen Bræ } \\
(4-70 \mathrm{~m})\end{array}$ \\
\hline & $\begin{array}{c}36 \mathrm{~m} \\
\mathrm{u} \\
\\
\end{array}$ & & $\begin{array}{l}\text { Academy } \\
\text { Gletscher } \\
(>900 \mathrm{~m})\end{array}$ \\
\hline
\end{tabular}

Fig. 4. Stratigraphy of the Independence Fjord Group in the type area between J. P. Koch Fjord and Danmark Fjord (Collinson, 1980, 1983). U, unconformities at base of siltstone members. Sandstone members are stippled.

Proterozoic and Lower Cambrian strata (Collinson, 1980).

The sediments of the Independence Fjord Group are only well known in the region between southern J. P. Koch Fjord and Danmark Fjord where the group has been formally subdivided into the sandstone-dominated Inuiteq S $\sigma$ and Norsemandal Formations (Adams \& Cowie, 1953; Jepsen, 1971; Collinson, 1980). These occur in geographically separated areas, between which correlation is uncertain (Fig. 4). Each formation consists of several sandstone members separated by laterally extensive siltstone members (Figs 4,5 ). In the Norsemandal Formation these siltstone members can be traced for more than $100 \mathrm{~km}$ (Collinson, 1980).

The sandstones, which make up the bulk of the group, are mainly medium-grained to coarse-grained and generally quartz-rich. They chiefly show trough and tabular cross-bedding, but are interbedded with parallel-bedded units up to several metres thick in which the sandstone beds are separated by silty interbeds up to 10 $\mathrm{cm}$ thick. Bedding surfaces commonly show current or wave ripples, often in interference patterns, dessication polygons and synaeresis cracks. Scattered throughout the sandstones are thin conglomerate beds comprising both exotic pebbles and mudstone intraclasts. The vertical interbedding of the different sedimentary facies within the sandstones seems to be random (Collinson, 1980, 1983).

The red siltstone members mainly comprise thinly and irregularly interbedded sequences of homogeneous

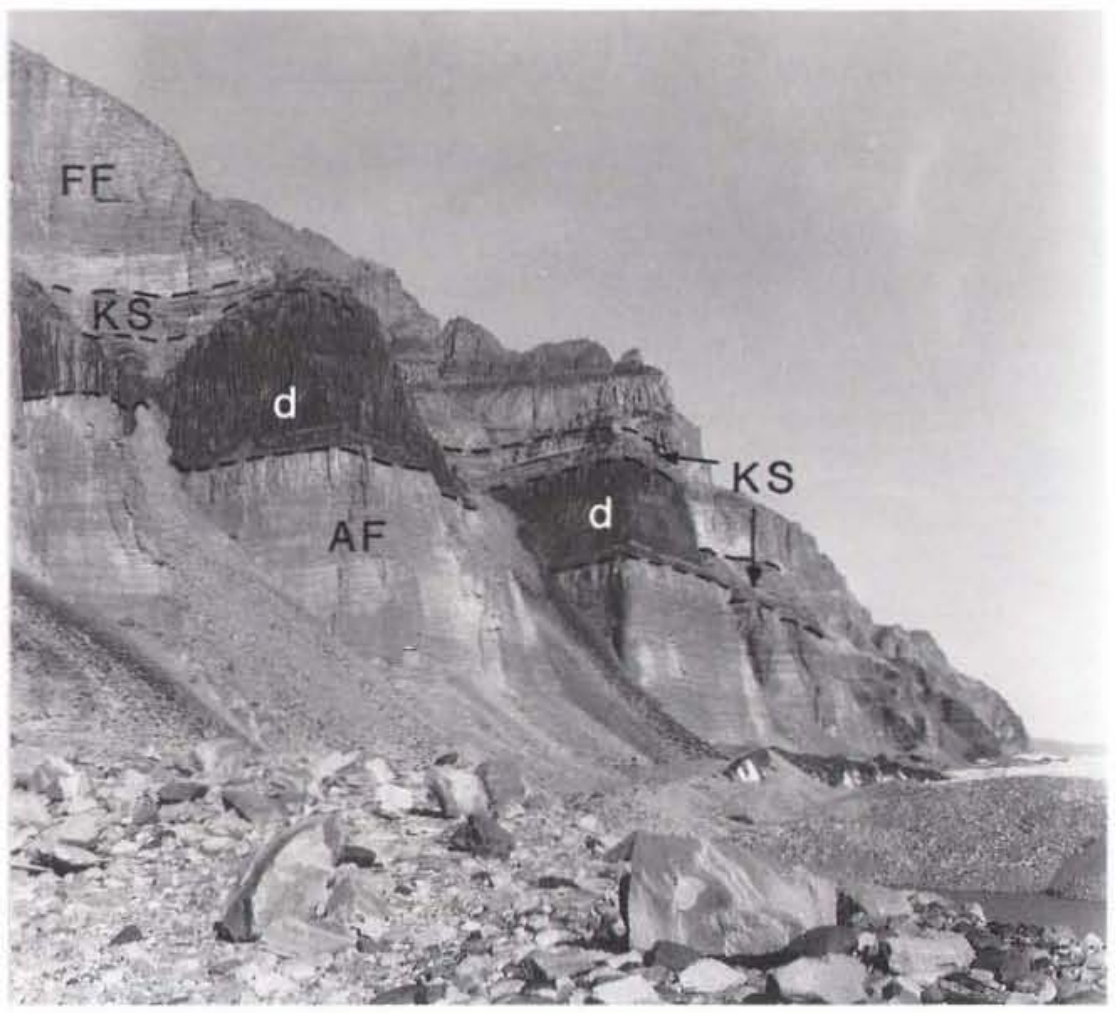

Fig. 5. Outcrops of the upper part of the Independence Fjord Group (Norsemandal Formation) in cliffs along the southern margin of J. C. Christensen Land. AF, Astrup Fjord Member $(290 \mathrm{~m})$; KS, Kap Stadil Member; FF, Fiil Fjord Member. A thick dolerite sill (d) of the Midsommersø Dolerite Formation occurs between the Astrup Fjord and Kap Stadil Members. 
Fig. 6. Interbedded sandstones and siltstones in the top of the Hagen Bra Member along the southern margin of J. C, Christensen Land. Height of section $c$. $40 \mathrm{~m}$.

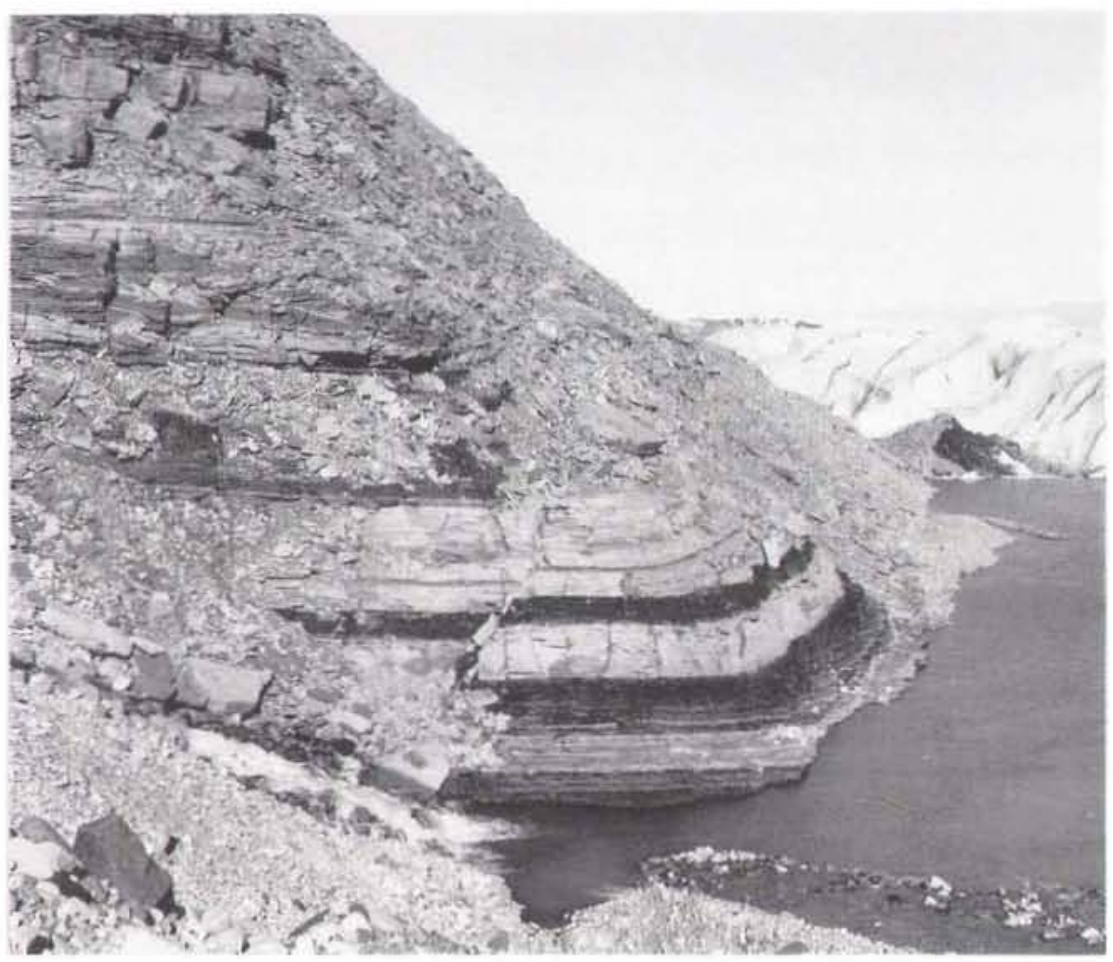

or rather poorly laminated coarse siltstones (sometimes with irregular dolomite concretions) and sandstones (Fig. 6). These sequences may show both upwards fining or coarsening. The sandstone beds are mostly less than $20 \mathrm{~cm}$ thick, but may reach $3.5 \mathrm{~m}$. Top surfaces of the thicker beds commonly show wave or current ripples, often with interference patterns. Lower surfaces often show casts of dessication polygons and halite pseudomorphs. Rare intercalations of dolomite in beds generally less than $50 \mathrm{~cm}$ thick show fine horizontal lamination and small laterally linked stromatolitic domes. The lower boundaries of the siltstone members are always sharp while the upper boundaries generally are gradational (Collinson, 1980, 1983).

The sedimentary features and the very widespread nature of the siltstone members suggest that they represent ephemeral saline lakes which often dried out to form extensive playas. The sandstone members record fluvial and aeolian sedimentation on very low angle alluvial fans which gradually filled in the lakes (Collinson, 1983; L. B. Clemmensen, unpublished data).

The sharp lower boundaries of the siltstone members show features suggesting significant breaks in deposition, such as developments of local palaeotopography up to $70 \mathrm{~m}$ high (Fig. 7), vertical, sharp-sided conglomerate filled fissures in the underlying sandstones, and basal conglomerates associated with silica-cemented concretion horizons (Collinson, 1983). Sediments associated with the palaeotopographies include flanking conglomerates, steeply dipping (up to $30^{\circ}$ ) thinly bedded sandstone beds with wave-rippled upper surfaces, and cryptalgally laminated dolomites containing evaporite nodules replaced by chalcedony. The latter deposits, which indicate slight emergence for sustained periods, drape palaeotopographies of up to $10 \mathrm{~m}$ and suggest that considerable fluctuation in lake level during this relatively submerged phase occurred. Thicker successions of evaporite may have developed in the deeper parts of the lake under such conditions and, at one locality, an angular discordance observed within the Hagen Bræ Member of the Norsemandal Formation could have been caused by later dissolution of the evaporites (Collinson, 1983).

The large extent of the siltstone members in the Norsemandal Formation suggests that lacustrine conditions were very extensive. This, together with the fact that each siltstone member is preceeded by an erosional phase, led Collinson (1983) to suggest that the pattern of overall subsidence was punctuated by intervals of uplift, followed by initially rapid subsidence of probably basin-wide extent. Very tentatively it was suggested that minor phases of heating and cooling at depth resulted in the widespread lacustrine intervals and that a much larger, but related, thermal event led to the extensive 


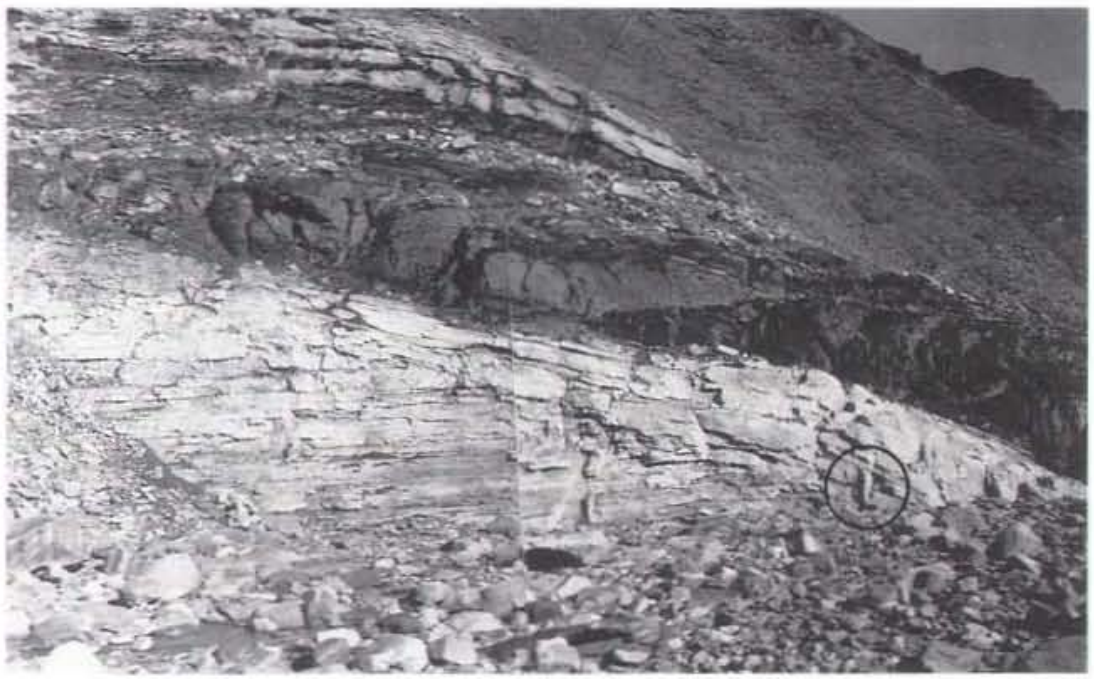

Fig. 7. Erosional relief on top of the Academy Gletscher Member with an overlying wedge of flanking sandstones in turn overlain by red siltstones of the Hagen Bre Member. Person (encircled) for scale. Southern margin of J. C. Christensen Land.

extrusion of the basalts which directly overlie the Independence Fjord Group.

\section{Middle Proterozoic continental rifting and volcanic activity}

Following the deposition of the Independence Fjord Group a major Middle Proterozoic event of extensive basic volcanic activity occurred in a more than $100 \mathrm{~km}$ wide belt curving along the present northern and eastern margin of the Canadian-Greenland Shield. $\mathrm{Rb} / \mathrm{Sr}$ and $\mathrm{K} / \mathrm{Ar}$ isotope analyses of the basic rocks have yielded ages between $1260-1100 \mathrm{Ma}$ (cf. Jackson \&
Ianelli, 1981). This important event probably represents rifting and continental break-up related to the opening of a pre-Grenvillian ocean (Jackson \& Ianelli, 1981).

In central and eastern North Greenland the crystalline basement and the Independence Fjord Group were intruded by huge volumes of basic magma (the Midsommers $\emptyset$ Dolerite Formation; Jepsen, 1971; Kalsbeek \& Jepsen, 1983). Where the magma reached the surface, the Independence Fjord Group was overlain by at least $1350 \mathrm{~m}$ of lava flows with a minimum extent of $10000 \mathrm{~km}^{2}$ (the Zig-Zag Dal Basalt Formation; Jepsen, 1971; Kalsbeek \& Jepsen, 1984).

In Dronning Louise Land in North-East Greenland
Fig. 8. Midsommersø Dolerite Formation intruded in sandstones of the Inuiteq Sø Formation (Independence Fjord Group). The intrusives consist of mobilised sandstone (rheopsammite) with a dark doleritic border zone. The bottom part of the section is occupied by a thick dolerite sheet. East-facing cliffs at the head of Independence Fjord; cliff height is approximately 600 $\mathrm{m}$.

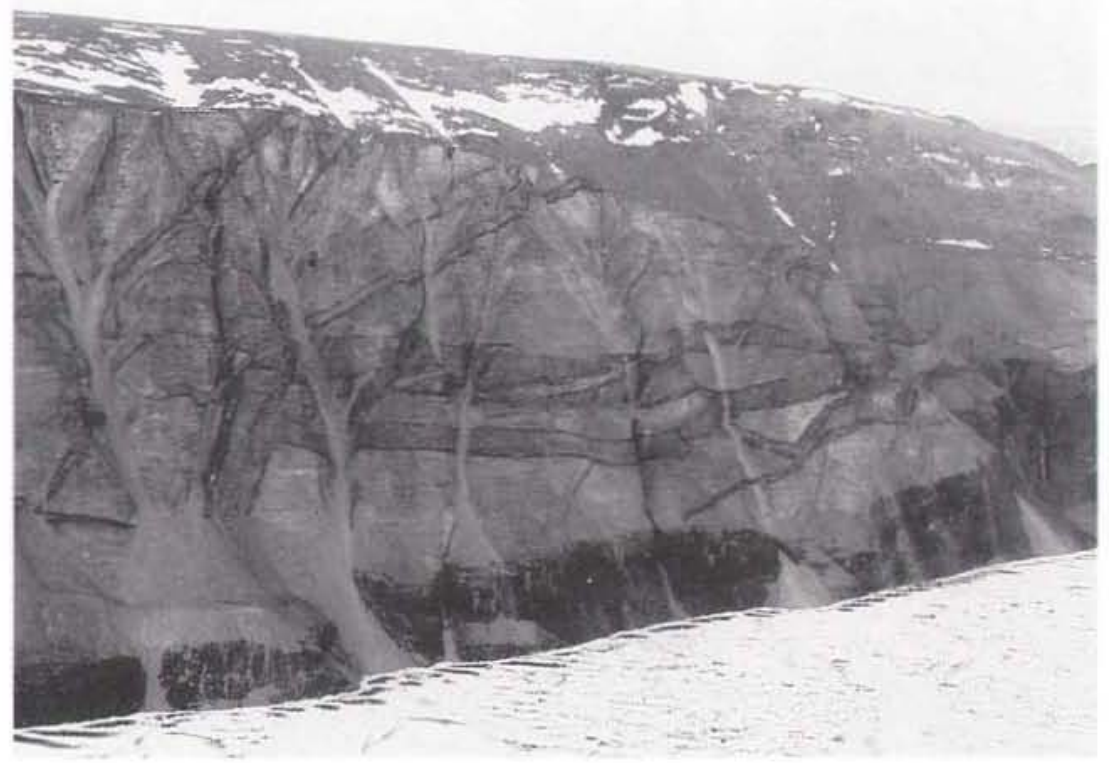




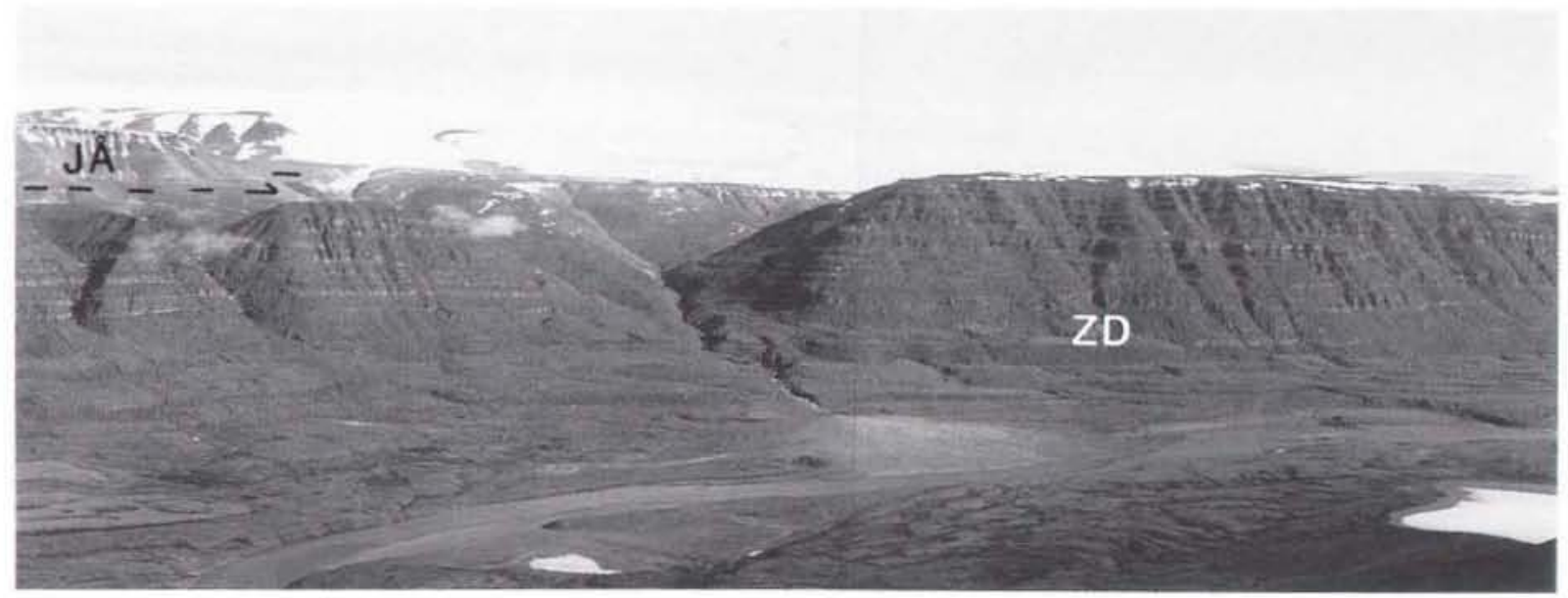

Fig. 9. Parallel bedded basaltic flows of the Zig-Zag Dal Basalt Formation (ZD) overlain by the Hagen Fjord Group (Jyske Ảs Formation, JA). Zig-Zag Dal. Section height of the basalts in the mountain in the foreground is c. $500 \mathrm{~m}$.

(Fig. 1) sediments correlated with the Independence Fjord Group (the 'Trekant series' of Peacock, 1956) are penetrated by numerous dolerite intrusions comparable to the Midsommers $ø$ Dolerite Formation (Friderichsen et al., 1990). In North-West Greenland and on Ellesmere Island the Thule Supergroup of partly Middle Proterozoic age contains lava flows and is intruded by several generations of basic rocks of which the oldest have yielded $\mathrm{K} / \mathrm{Ar}$ isotope ages of $1190 \mathrm{Ma}$ (Dawes \& Rex, 1986; P. R. Dawes, personal communication, 1990). In northern Canada Middle Proterozoic rocks are found in the lower part of the Borden Basin (Fig. 1). Middle Proterozoic basic volcanic activity has also been reported farther to the west in Canada, in the Coppermine area and the Great Slave area (cf. Jackson \& Ianelli, 1981).

The Midsommers $\emptyset$ Dolerite Formation is very widespread in the area between southern Peary Land and Kronprins Christian Land (Fig. 1). The intrusives occur as sheets, sills and dykes of dolerite and associated rocks. The intrusion types commonly pass into each other, often resulting in irregular and unpredictable outcrop patterns (Fig. 8). Flat-lying sheets of dolerite are most common; they range in thickness from a few metres up to several hundred metres and some of them can be followed for tens of kilometres. The aggregate thickness of the intrusions in many areas is probably at least $1000 \mathrm{~m}$.

The intrusive rocks can be subdivided into three main groups: 1 , normal dark grey to black dolerites; 2 , redbrown to brick red or greenish mottled rocks which may be very fine grained; 3 , very silicic rocks representing mobilised sandstones (rheopsammites). The different rock types are more or less contemporaneous. Intersec- tions are common but show no systematic age differences (Fig. 8).

The normal dolerites and their red-brown derivatives are chemically classified as quartz tholeiites and only in the basal cumulative parts of the intrusions are normative olivine and nepheline present. Whole-rock $\mathrm{Rb} / \mathrm{Sr}$ isotope data from the intrusive rocks give ages of about $1230 \mathrm{Ma}$. Previous $\mathrm{K} / \mathrm{Ar}$ isotope age dates (Henriksen \& Jepsen, 1970), which indicated ages ranging from $c$. 800 to $1000 \mathrm{Ma}$, are now regarded as unreliable due to Ar mobility (Kalsbeek \& Jepsen, 1983).

The Zig-Zag Dal Basalt Formation (Figs 9, 10) which overlies the Independence Fjord Group in eastern North Greenland represents the effusive equivalent of the Midsommersø Dolerite Formation. Attempts to date the basalts by $\mathrm{Rb} / \mathrm{Sr}$ whole-rock analysis have failed but similarity in chemistry and palaeomagnetism (Marcussen \& Abrahamsen, 1983) supports the evidence for the two formations being contemporaneous.

The Zig-Zag Dal Basalt Formation mainly outcrops in the region between Danmark Fjord and Independence Fjord (Fig. 1). In this area the basaltic succession occupies a trough-shaped basin (Fig. 3) which apparently underwent subsidence after, and probably also during, the volcanic activity.

Prior to the deposition of the Late Proterozoic Hagen Fjord Group, the underlying sequences, including the volcanics, were block-faulted and peneplained. Thus, the thickness of the basalts varies from $c .100 \mathrm{~m}$ at the northern and southern extremities of the main outcrop area to $c .1350 \mathrm{~m}$ in the central part. It is probable that the basalts originally occupied a much larger area since the associated intrusions are very numerous in the area west and south-west of the present basalt outcrop. 


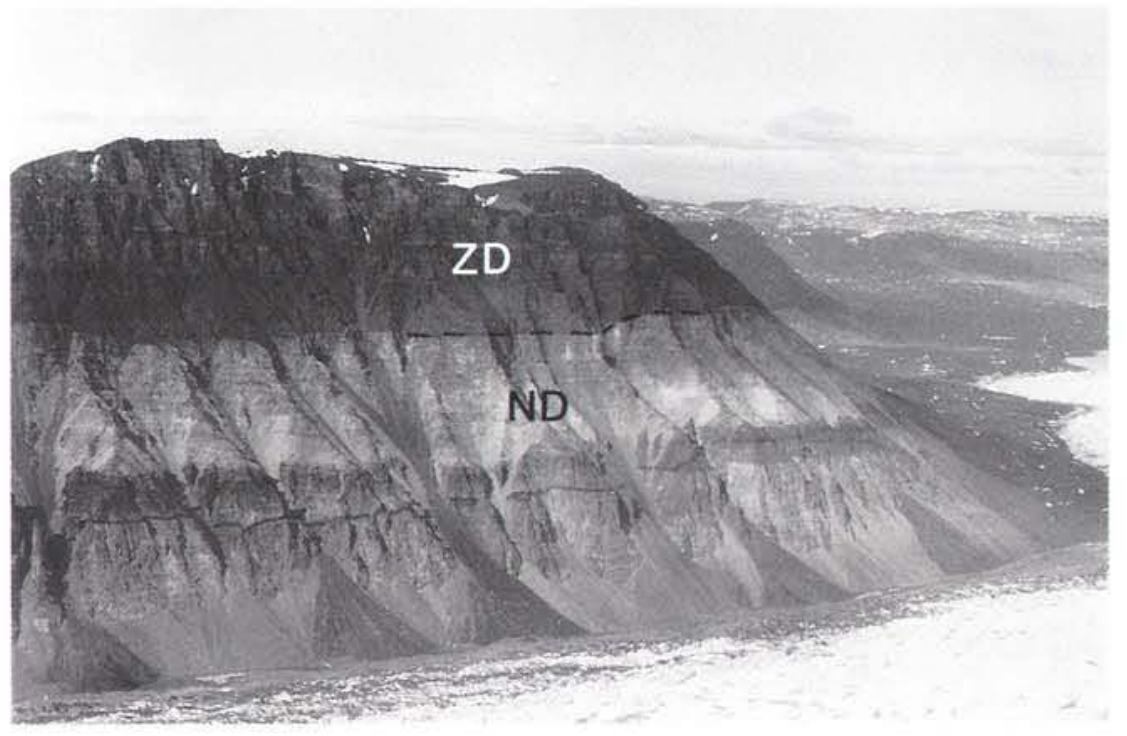

Fig. 10. Base of the Zig-Zag Dal Basalt Formation (ZD) overlying sandstones of the Independence Fjord Group (Norsemandal Formation, ND) along the southern coast of J. C. Christensen Land. Cliff height is $c .800 \mathrm{~m}$.

Moreover, some $200 \mathrm{~m}$ of the Zig-Zag Dal Basalt Formation are found $100 \mathrm{~km}$ north-east of Independence Fjord in an uplifted fault block in eastern Peary Land; minor occurrences have also been found in the Hekla Sund area in eastern Kronprins Christian Land (Fig. 1). In both cases the basalts are associated with dolerite intrusives and sandstones of the Independence Fjord Group.
The Zig-Zag Dal Basalt Formation can be subdivided into three units in ascending order: the basal unit, the aphyric unit and the porphyritic unit (Jepsen et al., 1980). The basal unit is $100-120 \mathrm{~m}$ thick and is composed of thin, macroscopically aphyric basalt flows, varying in thickness from less than $1 \mathrm{~m}$ to $10 \mathrm{~m}$. Pillow lavas locally occur in the lower part, suggesting subaqueous effusion of at least the lower part of the unit. A thin

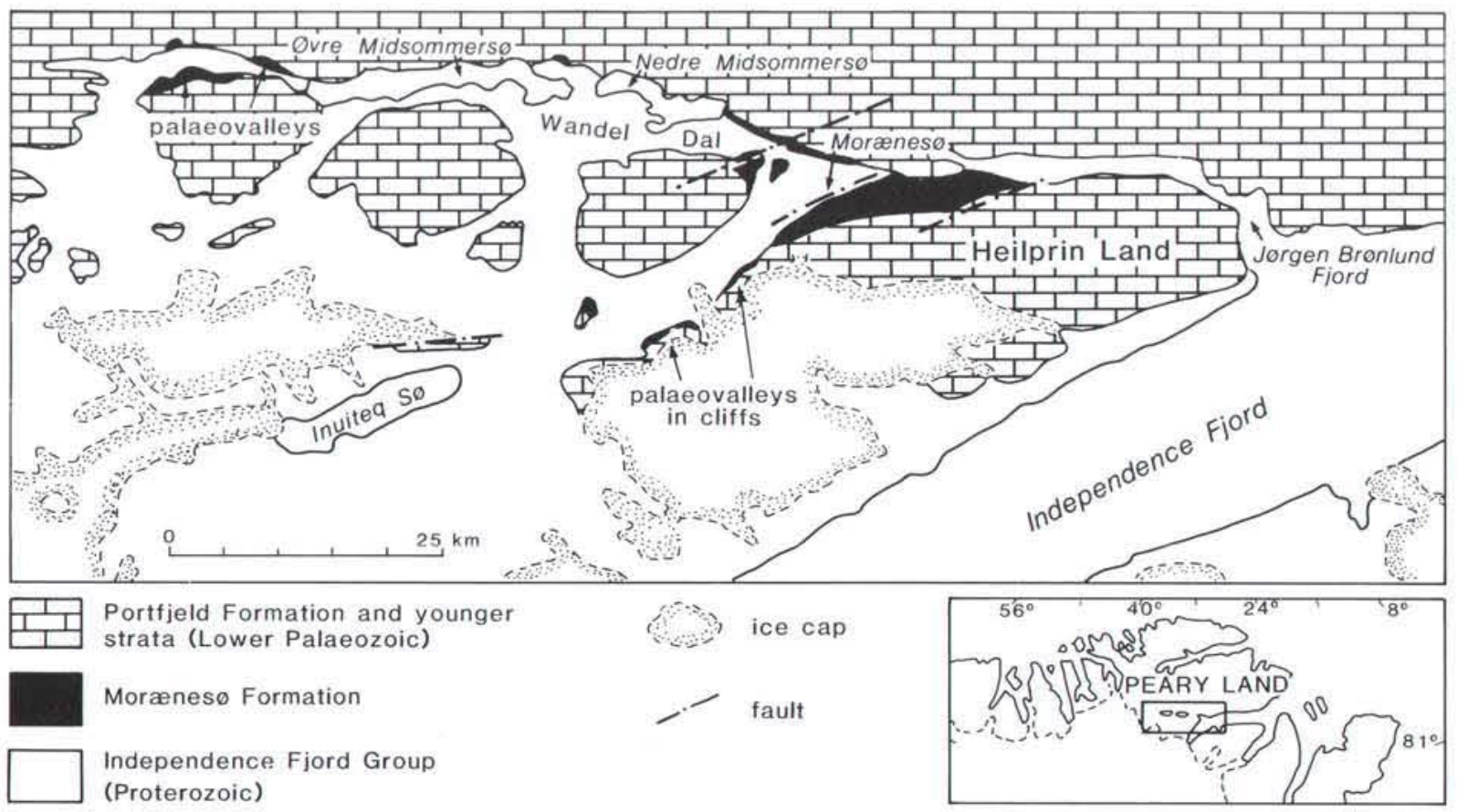

Fig. 11. Map showing the distribution of outcrops of the Morænes $\emptyset$ Formation in the type area in southern Peary Land. 
sediment horizon consisting of sandstone and dolomite locally overlies the basal unit and apparently marks a break in the volcanic activity.

The aphyric unit (390-440 m) and porphyritic unit (up to $750 \mathrm{~m}$ ) are together composed of about 30 flows, varying in thickness from 10 to $120 \mathrm{~m}$. Most flows have non-erosional tops indicating that the basalts were extruded within a short period of time. Some of the thicker flows can be traced laterally for more than 100 $\mathrm{km}$ and a volume of at least $600 \mathrm{~km}^{3}$ has been estimated for one single flow (Kalsbeek \& Jepsen, 1984). In one section a $100 \mathrm{~m}$ thick succession of rhyolitic flows is located near the top of the aphyric unit but the strongly altered red-coloured flows have not been investigated in detail. The lower part of the porphyritic unit changes character laterally. The flows in this interval are relatively thin and cannot be traced from section to section; sediments and pillow lava horizons are present and local erosional relief of up to $50 \mathrm{~m}$ has been observed. Volcanic activity was apparently less intense in the period following the deposition of the aphyric unit, and temporary breaks in the volcanic activity occurred before the main part of the porphyritic unit was formed.

Following the formation of the basaltic successions a long hiatus of at least $400 \mathrm{Ma}$ occurred before any sedimentary record is preserved in North Greenland (Figs 1,2). Grenvillian plate collision took place around $1100-1000 \mathrm{Ma}$ along the northern margin of the Canadian Shield resulting in intense deformation (Trettin, 1987). No direct information of this orogenic event is known from North Greenland, although it may have influenced the degree of uplift and erosion prior to the deposition of the Morænes $\emptyset$ Formation and the Hagen Fjord Group (Jepsen \& Kalsbeek, 1985).

\section{Late Proterozic sedimentation}

The youngest of the Proterozoic sedimentary basin phases in North Greenland occurred along the northwestern margin of the Iapetus Ocean. Two different major depositional settings can be recognised during this phase; a mainly continental setting dominated by post-glacial reworking, and a marine setting dominated by sedimentation of a subsiding shelf and trough.

\section{Late Proterozoic glaciation}

The Morænes $\emptyset$ Formation (Jepsen, 1971) records a Late Proterozoic glacial event in North Greenland. These deposits were first described by Troelsen (1956) who interpreted them as tillitic due to the presence of diamictites together with facetted and striated clasts. Later, Clemmensen $(1979,1981)$ and Collinson et al.
(1989) stated that most of the deposits are fluvial, lacustrine or aeolian facies formed during post-glacial reworking, and that only a minor part of the formation is of possible glacial origin.

The Morænes $\emptyset$ Formation is only well known in the type area around Wandel Dal where it occurs as a series of palaeovalley fills, but it also occurs as scattered outcrops around the head of Victoria Fjord (Figs 1, 11; Collinson et al., 1989; Henriksen, 1989). In the type area the Morænes $\varnothing$ Formation is dominated by sandstones, diamictites, conglomerates and breccias with a minor although important interval of stromatolitic dolomite near the top of the exposed succession. Unconformities bound the formation both above and below; the lower of these shows considerable relief while the upper is extremely flat and truncates pre-Morænes $\varnothing$ strata and syn-Morænes $\varnothing$ Formation palaeotopography (Fig. 12). Underlying rocks consist of the sandstones and associated intrusive dolerites of the Inuiteq Sø Formation (Independence Fjord Group). Above the upper unconformity the Lower Cambrian Portfjeld Formation consists of a basal 1-2 m glauconitic sandstone unit which passes up into a thick mainly carbonate succession (Jepsen, 1971; Higgins et al., 1991).

Acritarchs obtained from the Morænes $\varnothing$ Formation are not age diagnostic (G. Vidal, GGU internal report, 1982) but stratigraphic considerations suggest that the Morænesø Formation at least in part is related to the Late Proterozoic (Varangian) glaciation also known from North America, Canada, East Greenland, Spitsbergen and Europe (Hambrey \& Harland, 1981; Hambrey, 1988; Collinson et al., 1989). Like the Morænes $\emptyset$ Formation the tillite-bearing succession of Varangian age of central East Greenland and Spitsbergen is separated by a hiatus from the overlying Lower Cambrian sequence (Hambrey \& Spencer, 1987; Hambrey, 1988). Furthermore, diamictites found in a palaeovalley setting similar to the Morænesø Formation are also known from the lower of the Varangian tillites in Finnmark (Føyn \& Siedlecki, 1980).

The unconformity at the base of the Morænesø Formation reflects a palaeorelief of at least $190 \mathrm{~m}$. Given the shapes of the preserved palaeovalleys and the great distances between some of them, however, a total relief of several hundreds of metres could have been present immediately prior to the deposition of the Morænes $\emptyset$ Formation (Collinson et al., 1989).

Direct evidence of the erosive process has only been observed at one locality where a diamictite containing striated clasts of glacial origin directly rests upon heavily disintegrated sandstones of the Inuiteq S $\varnothing$ Formation. This diamictite may represent the only preserved in situ till in the whole area. At all other localities diamictites 


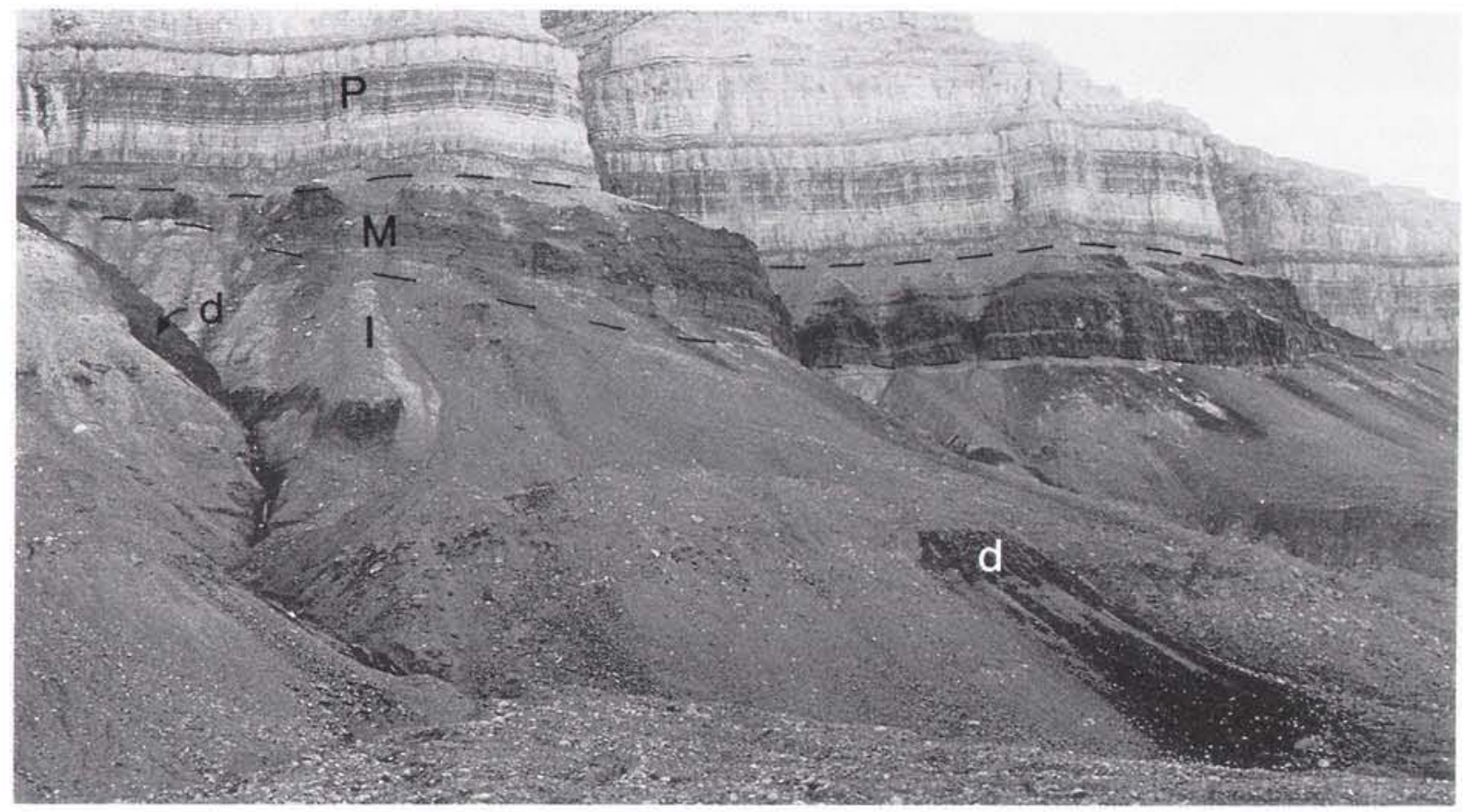

Fig. 12. Cliff-exposure of a palaeovalley cut into the sandstones of the Independence Fjord Group (Inuiteq Sø Formation, I) into which dolerites (d) of the Midsommers $\emptyset$ Dolerite Fomation have been intruded. The dark sediments of the Morænes $\emptyset$ Formation (M) thin away to either side and are overlain by the Cambrian Portfjeld Formation (P). Cliff section east of Inuiteq S $\emptyset$, Fig. 11. Maximum thickness of Morænesø Formation is approximately $100 \mathrm{~m}$.

are always separated from the unconformity by waterlain and aeolian sediments (Collinson et al., 1989, p. 20). The broadly concave upwards, rounded forms of the palaeovalleys in cross-section (Fig. 12) could be taken as an argument for glacial erosion.

Directly overlying the basal unconformity, the deeper, more axial parts of the palaeovalleys contain sandstones and conglomerates of mainly fluvial origin, locally with some lacustrine and aeolian intervals. These deposits record initial valley floor aggradation prior to the deposition of the diamictites. Fluvial activity was ephemeral, as suggested by the presence of sands reworked into aeolian dunes, but capable of transporting clasts up to $1 \mathrm{~m}$ in diameter and of forming large gravel bedforms. Considering that glaciers probably were involved in the erosion of the palaeolandscape, nearly all the deposits on the valley floor must have been eroded and reworked by this later fluvial activity. Evidence that the climate was at least seasonally cold during this phase is provided by dropstones in local lake deposits and by the presence of locally derived breccias. The latter were the products of a suite of gravity-driven mass movement processes, some of which are enhanced by freeze-thaw processes in cold climates (Collinson et al., 1989).

The early valley floor sediments are overlain by diam- ictites (Fig. 13) which were deposited from mobile debris flows, possibly in a series of closely spaced events. The diamictites contain both local and exotic clasts, some of the latter being flat-iron shaped and striated. The textures and clasts of the diamictites suggest an earlier phase of glacial transport. Parts of these units show evidence of movement towards the valley axis, suggesting they were most likely derived from earlier lateral moraines deposited higher on the valley side, or as tills within hanging valleys, at a time when a glacier occupied the main valley. The remobilisation of these deposits occurred under a more humid period of climatic amelioration some time, perhaps thousands of years, after deglaciation of the region. This inference is supported by the presence of valley floor sediments which were deformed due to intense water saturation by mass flows. Similarly, deep spheroidal weathered dolerites close to the basal unconformity are unlikely to have survived a phase of glacial erosion; their deep weathering is more likely to have occurred after the initial erosion of the valley (Collinson et al., 1989).

The uppermost beds of the Morænes $\emptyset$ Formation sharply overlie the highest diamictite sheet and comprise a lower dolomite unit up to a few metres thick showing domal stromatolites (Fig. 14), and an upper 
Fig. 13. Typical texture of diamictite with subhorizontal partings and well dispersed fabric. Hammer is $35 \mathrm{~cm}$ long.

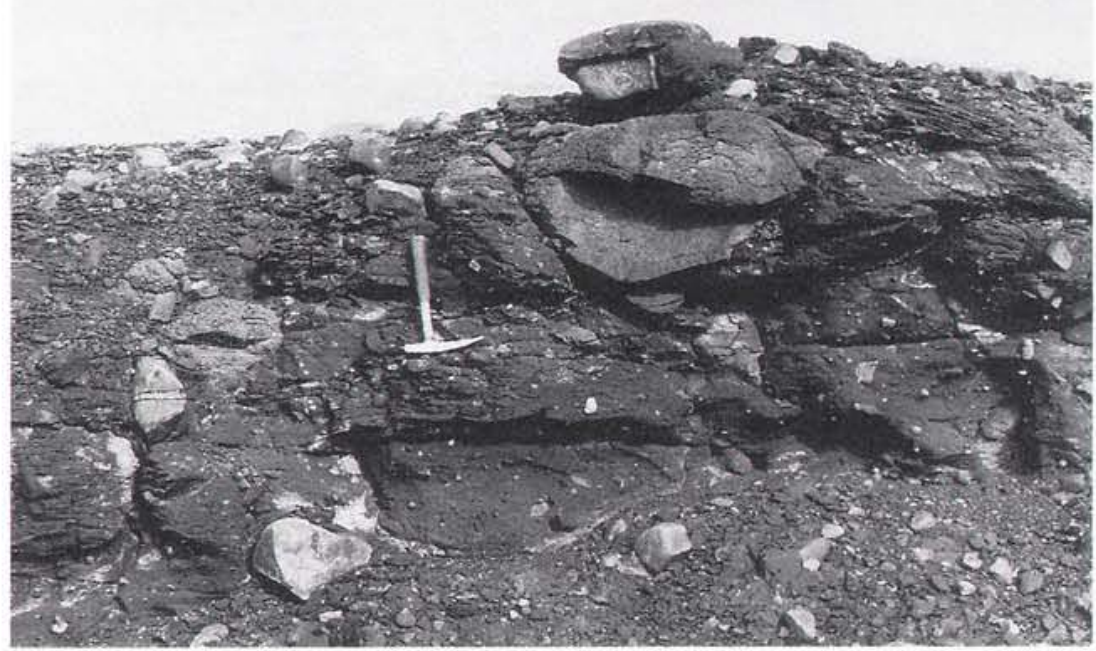

thin unit of sandstone, infilling and draping the stromatolite domes. These beds record the establishment on the valley floor of shallow-water environments in which algal stromatolites flourished. This occurred with mini- mal reworking of the diamictites, suggesting low energy conditions during transgression. The stromatolite domes are laterally linked, up to $2 \mathrm{~m}$ high and $8 \mathrm{~m}$ in diameter; they are generally circular in plan view (Fig.

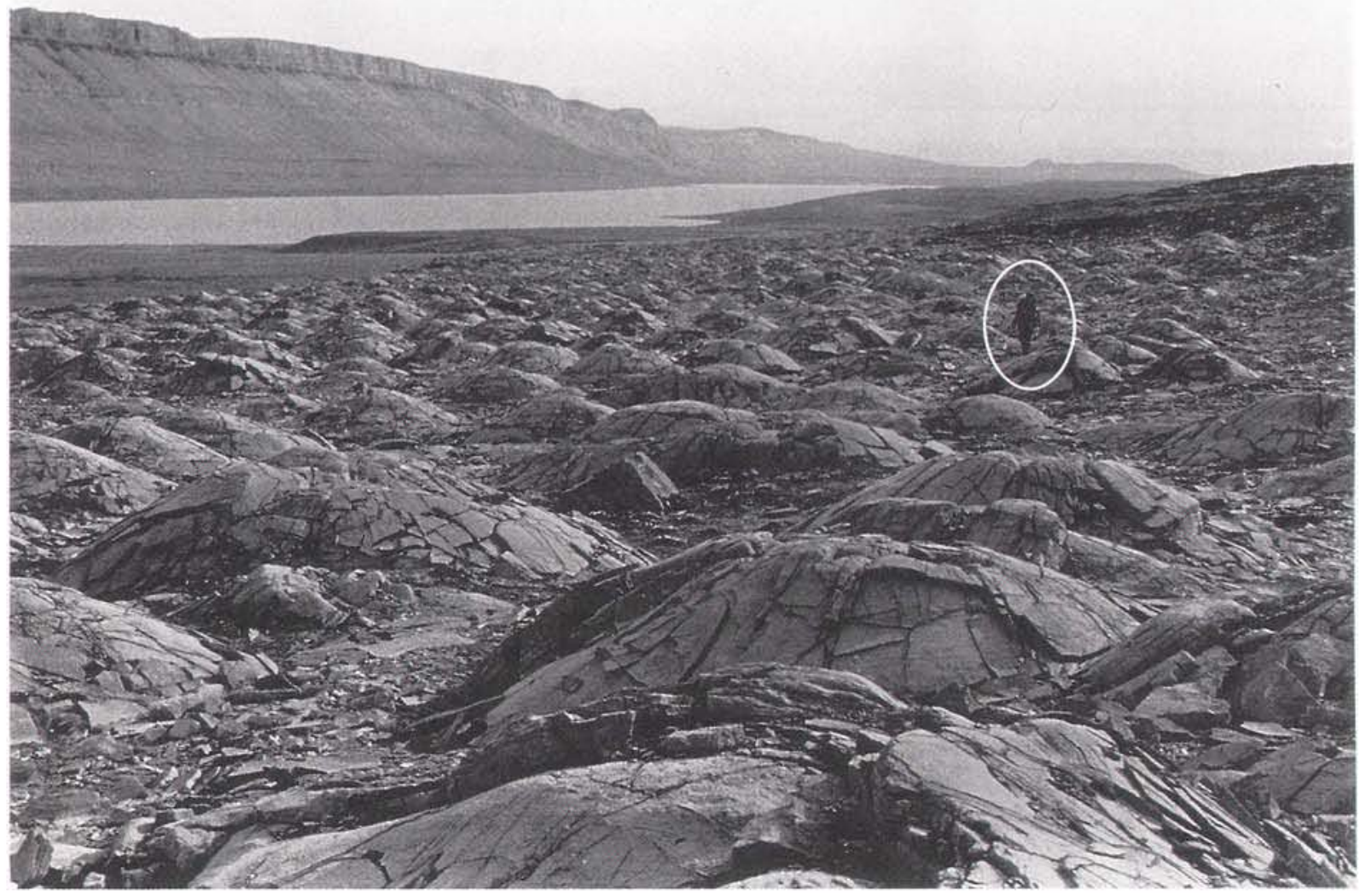

Fig. 14. Extensive bedding surface showing stromatolite domes within the upper part of the Morænesø Formation, western end of Jørgen Brønlund Fjord. Person (encircled) for scale. 
Fig. 15. Cliff section of the Hagen Fjord Group just south of Kap Bernhard, J. C. Christensen Land. CD, Campanuladal Formation; FS, Fyns Sø Formation; JÅ, Jyske Ås Formation; KB, Kap Bernhard Formation; ZD: Zig-Zag Dal Formation. The Hagen Fjord Group is overlain by the Lower Cambrian Portfjeld Formation (P). The thickness of the Campanuladal Formation is $175 \mathrm{~m}$.

14). The domal stromatolites are capped by a thin coarsening-upwards siltstone and sandstone unit reflecting the re-establishment of clastic supply to a wave-aggitated setting, possibly a beach or a shoreface. There is no clear evidence within the algal stromatolites as to whether the widespread development of shallow water environments was related to intervals when lakes formed on the valley floors or to a marine ?glacioeustatic transgression (Collinson et al., 1989).

\section{Late Proterozoic shelf and trough sedimentation}

Late Proterozoic shelf and trough sediments in North Greenland are represented by the mainly shallow marine Hagen Fjord Group (up to $1000 \mathrm{~m}$ thick; Clemmensen \& Jepsen, in press) and partly equivalent deepwater deposits referred to the more than $2500 \mathrm{~m}$ thick Rivieradal sandstones (sensu Hurst \& McKerrow, 1981a) (Figs 2, 3). Outcrops of the Hagen Fjord Group are seen in the type region between the north-western side of Independence Fjord and Danmark Fjord, where sediments assigned to the group onlap the Independence Fjord Group and Zig-Zag Dal Basalt Formation with a very low angle unconformity (Fig. 1). In the area around Centrum $S \emptyset$ in Kronprins Christian Land, Hagen Fjord Group sediments conformably overlie the Rivieradal sandstones within large nappe structures (Figs 1-3; Hurst \& McKerrow, 1981a). Between Kronprins Christian Land and Dronning Louise Land, possible correlatives of the Hagen Fjord Group overlie strata assigned to the Independence Fjord Group and associated basalts with a marked unconformity (Friderichsen et al., 1990; Clemmensen \& Jepsen, in press). The upper boundary of the group in the type area is a remarkably flat unconformity overlain by the Lower Cambrian Portfjeld Formation. At Kap Holbæk, furthest to the south-east in Mylius-Erichsen Land, and in Kronprins Christian Land this unconformity is truncated by the sub-Wandel Valley Formation unconformity, however, and the Hagen Fjord Group is thus overlain by the Ordovician Wandel Valley Formation (Fig. 3; see below).

In central and eastern North Greenland, the Hagen

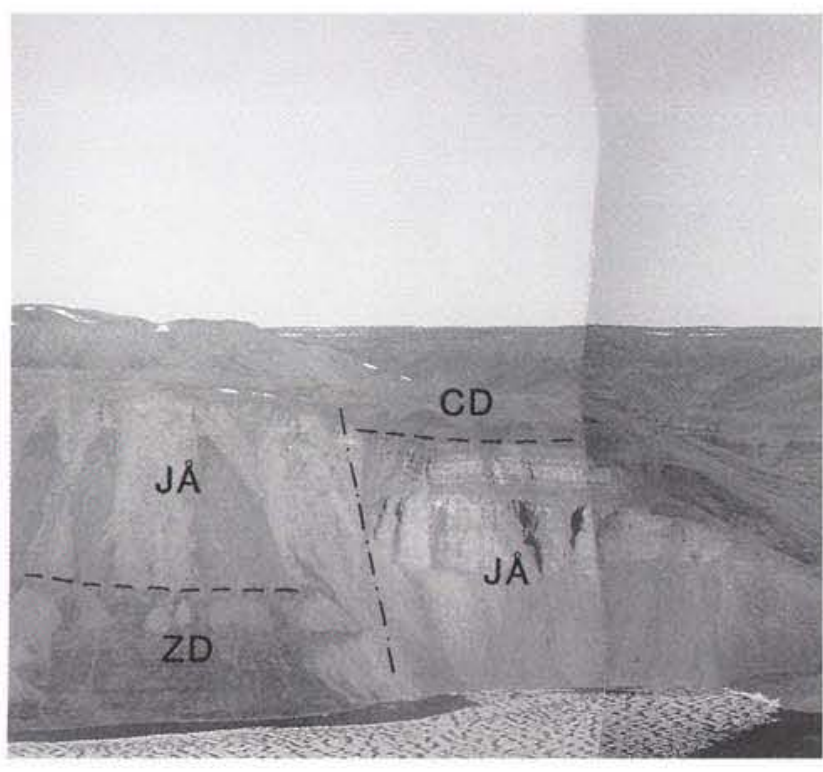

Fjord Group is divided into six formations (Figs 3, 15). The lowest is the Jyske Ås Formation (up to $c .500 \mathrm{~m}$ ), which is overlain by the Campanuladal Formation (up to $175 \mathrm{~m}$ ) in most of the area, and the Catalinafjeld Formation (up to $c .350 \mathrm{~m}$ ) furthest to the north-west (Fig. 3). These formations, all consisting of siliciclastic sediments, are followed by the Kap Bernhard Formation (up to $215 \mathrm{~m}$ ) which is dominated by limestones. This is overlain by a conspicuous yellow weathering dolomite unit, referred to the Fyns Sø Formation (up to $325 \mathrm{~m}$ ). The top of the Hagen Fjord Group is formed by sandstones of the Kap Holbæk Formation (up to 150 $\mathrm{m})$.

The Rivieradal sandstones sensu Hurst \& McKerrow (1981a) are only found within large nappe structures in Kronprins Christian Land (Fig. 16). Hurst \& McKerrow $(1981 b, 1985)$ suggested that the nappes were derived from the east or south-east and were displaced for distances in the order of 100 to $150 \mathrm{~km}$. The Rivieradal sandstones form a c. $2500 \mathrm{~m}$ thick deep-water turbidite succession which, in the lower part, is dominated by mudstones (now shales and phyllites). These pass upwards into interbedded sandstones and mudstones and massive thick-bedded sandstones. Conglomerates occur at two distinct horizons. The conglomerates consist of rounded to spherical clasts of which $95-98 \%$ are quartzite and $2-5 \%$ are dolerite, indicating derivation from the sandstones of the Independence Fjord Group and their associated volcanics.

The Hagen Fjord Group conformably overlies the Rivieradal sandstones, indicating evolution from deep 


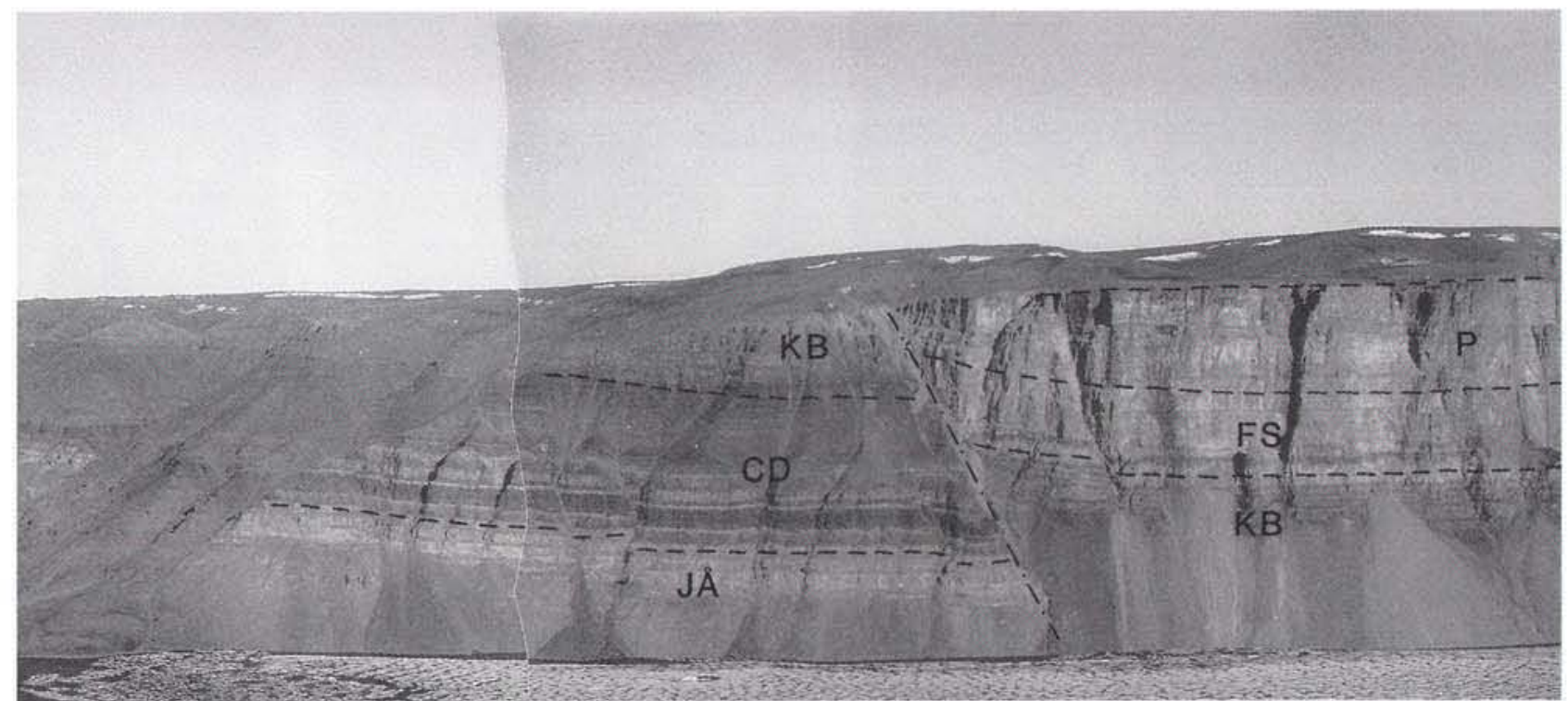

water sedimentation into shallow shelf sedimentation (Fig. 3; Hurst et al., 1985). The sedimentary and stratigraphic relationships between the Rivieradal sandstones and the Hagen Fjord Group are not yet fully elucidated, however, due to tectonic complexities associated with the Caledonian orogenesis in this little-studied area.

The Jyske Ås Formation records the marine transgressive event following the long hiatus represented by the sub-Hagen Fjord Group unconformity; it mainly consists of medium-grained sandstones internally dominated by cross-bedding. Foresets are sometimes covered by thin muddy drapes or may contain mudflake conglomerates at the base. Herringbone cross-bedding is present indicating a bimodal NE-SW palaeocurrent pattern with a dominant sediment transport towards NE. Current and wave-ripple cross-lamination and horizontal lamination occur locally in the sandstones, together with dessication cracks. Generally the formation lacks sequential patterns; thick coarsening-upwards sequences are locally present, however, and mudstone units up to several metres thick intercalated with sandstones only occur in the upper half of the formation. Although the basal part of the formation may include some fluvial deposits, the main part is interpreted to be of beach to shallow tidal shelf origin (Clemmensen \& Jepsen, in press).

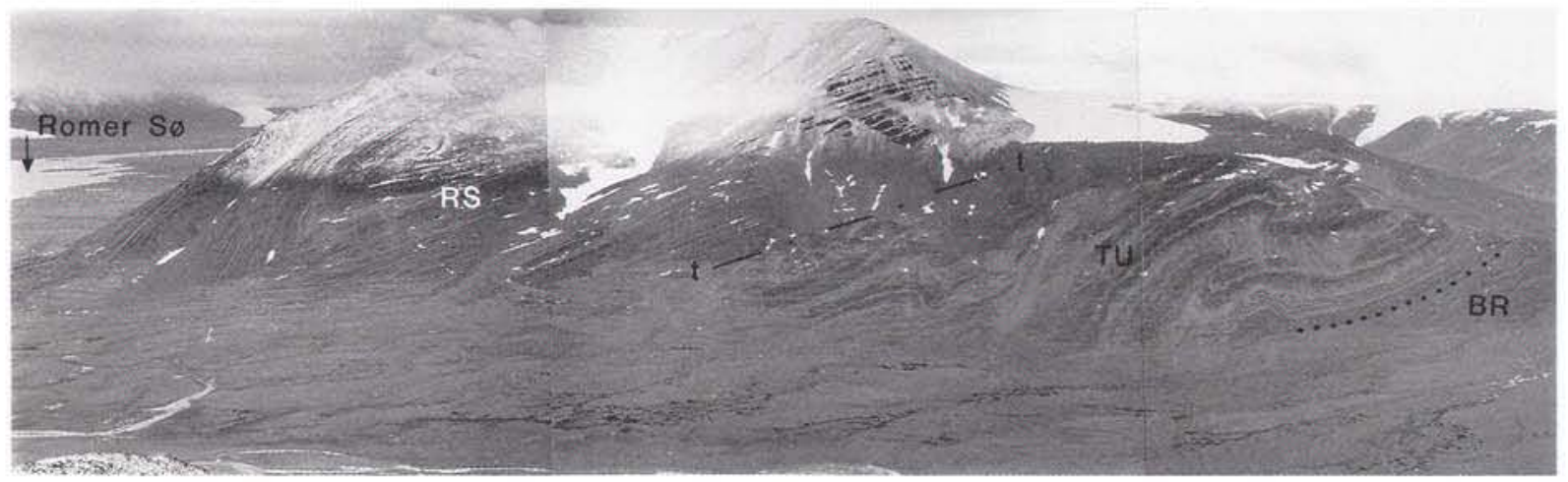

Fig. 16. Rivieradal sandstones (RS) as exposed in a thrust sheet on the western side of Romer Sø, Kronprins Cristian Land (Fig. 1, loc. 11). At this locality, the Rivieradal sandstones overlie Ordovician and Silurian carbonates of the Franklinian Basin (BR, Børglum River Formation; TU, Tures $\emptyset$ Formation) with a thrusted contact (t). Cliff-face is approximately $700 \mathrm{~m}$ high. 
The Campanuladal Formation, which overlies the Jyske Ås Formation in most of the area, consists mainly of a variegated sandstone and siltstone succession arranged in a characteristic sequence recognisable at most localities. The lower part of the formation consists of a variegated red and green or predominantly green unit of fine sandstone and siltstone. The upper part of the formation, which forms an excellent marker horizon throughout most of the outcrop area, consists of a stromatolitic dolostone unit overlain by green sandstones and siltstones with characteristic intercalations of yellow quartzitic sandstone beds. The green sandstones and siltstones display a coarse rhythmic interbedding. Internally, they are dominated by horizontal lamination and lenticular bedding, and dessication cracks are rare. Conspicuous gutter casts showing a preferred NE-SW orientation occur frequently along the sole of the green sandstone beds at most localities. The red sandstones and siltstones are similar; current and wave formed cross-lamination is much more abundant, however, and dessication cracks occur frequently. The features of the red sandstones and siltstones suggest deposition within the intertidal to supratidal zone, while the green sandstones and siltstones probably reflect deposition in intertidal to subtidal environments. The persistent orientation of the gutter casts, which is in accordance with the dominant flow direction in the underlying Jyske Ås Formation, suggests that the open sea was to the northeast. The stromatolitic dolostones in the upper part of the formation probably developed in shallow subtidal environments as a response to reduced clastic influx (Clemmensen \& Jepsen, in press).

Furthest to the north-west within the outcrop of the Hagen Fjord Group, along the coasts of Independence Fjord, the Catalinafjeld Formation forms a possible lateral equivalent of the Campanuladal Formation (Figs 1, 3; Clemmensen \& Jepsen, in press). On the northwestern side of Independence Fjord the Catalinafjeld Formation mainly consists of grey laminated mudstones with minor amounts of thin turbiditic sandstone beds. The mudstones show a distinct horizontal lamination consisting of alternating silty or fine-grained sandy and clayey laminae. Cross-lamination in the turbidites indicates palaeotransport directions towards the east. South of Independence Fjord the same lithologies are arranged in one, maybe two coarsening and thickeningupwards sequences. These sediments are considered to represent flooding and the establishment of deeper marine environments into the area (Clemmensen \& Jepsen, in press).

The Kap Bernhard Formation rather abruptly overlies the Campanuladal Formation and marks the change from siliciclastic to carbonate deposition within the Ha- gen Fjord Basin. The formation consists of reddishbrown limestones with minor amounts of terrigenous silt associated with thin siliciclastic siltstone beds. In the lower part of the formation, soft sediment deformation structures are abundant, and intraformational breccias are locally conspicuous. Upwards the degree of soft sediment deformation decreases and intervals with horizontal lamination, wave ripples and small pockets with intraformational edge-wise breccias appear. Stromatolitic units up to $20 \mathrm{~m}$ thick occur locally in the upper part of the formation. These sediments were probably deposited in a subtidal lagoon and the rather sudden shift from siliciclastic shelf deposition to incipient carbonate platform deposition may relate to a climatic change towards more arid conditions (Clemmensen \& Jepsen, in press).

Following the incipient platform deposits of the Kap Bernhard Formation, the Fyns $\ \varnothing$ Formation records the establishment of a true carbonate platform (sensu Read, 1982). The formation consists of generally massive, yellow weathering dolostone which, in the upper part of the formation, is commonly interbedded with thin red or green terrigenous siltstones. Locally, however, sedimentary structures are preserved within the dolostones; these include slump structures, intraformational breccias and rare ripple marks. Stromatolitic horizons occur throughout the formation; they are especially common in the uppermost part where they locally form spectacular composite linked mounds with a relief of up to $2 \mathrm{~m}$ (Fig. 17; Clemmensen \& Jepsen, in press). Conical columnar stromatolites ('conophyton') have also been reported from the formation (Adams \& Cowie, 1953). These stromatolites were probably restricted to subtidal environments and often form the exclusive stromatolitic component in basinal and slope deposits; such stromatolite facies have been recognised as a transitional facies in incipient and terminally drowned platforms (Donaldson, 1976; Hoffman, 1976; Grotzinger, 1989). The co-occurrence of 'conophyton' and slumped horizons in the Fyns $\ \emptyset$ Formation suggests subtidal deposition on the slope of a carbonate platform.

The last preserved phase in the evolution of the Hagen Fjord Basin is recorded by the Kap Holbæk Formation which marks the return to siliciclastic deposition and the resultant destruction of the earlier carbonate platform. The boundary between the Kap Holbæk Formation and the Fyns $\mathbf{S} \varnothing$ Formation is well defined although not exposed in detail. The lowermost part of the Kap Holbæk Formation consists of a thin unit of variegated mudstones including thin sandstone beds while the remaining part comprises fine-grained to occasionally coarse-grained sandstones and associated mud- 
Fig. 17. Composite linked stromatolite mounds of the Fyns Sø Formation in western Kronprins Christian Land.

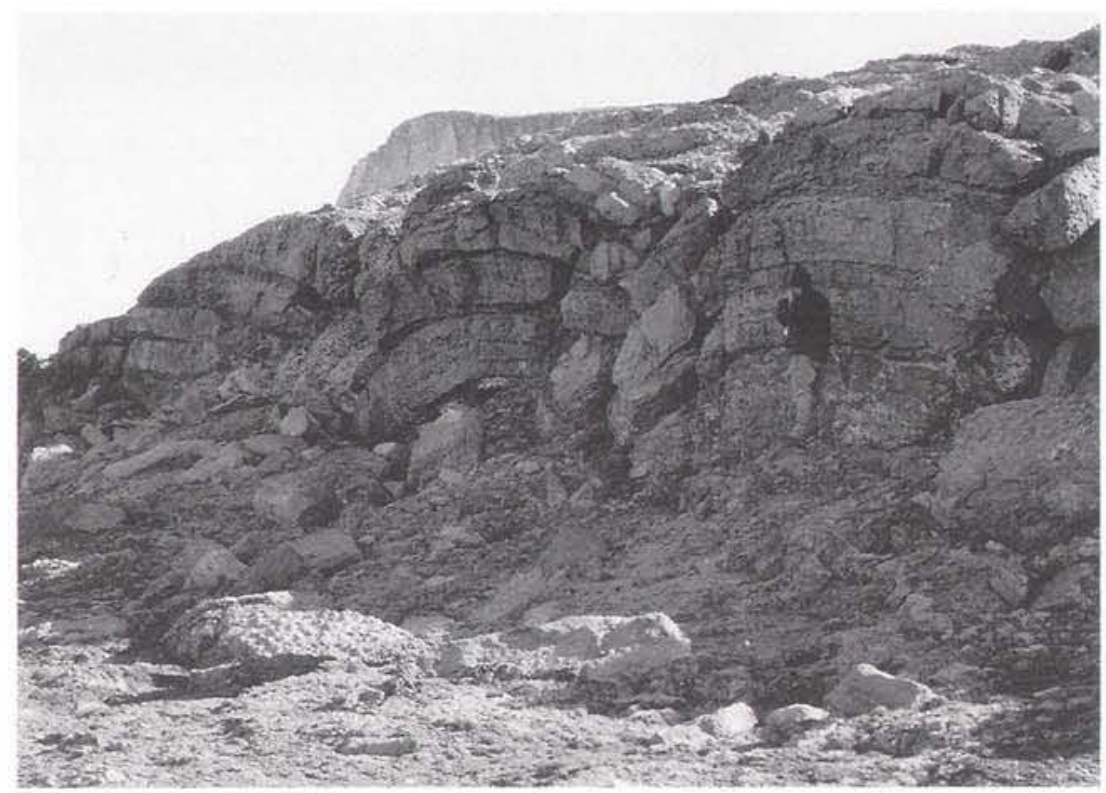

stones. Glauconite is common in the upper part of the formation. The sandstones are internally massive or show trough cross-bedding, herringbone cross-bedding and rare wave-ripples. Locally the formation contains planar cross-bedded sets up to $8 \mathrm{~m}$ thick. Skolithos-like burrows occur at a few horizons. In the lower part of the formation, the lithologies apparently show random interbedding but one well developed coarsening-upwards sequence is present near the top of the formation. Apparently, the sediments of the Kap Holbak Formation were deposited in shallow shelf to beach environments (Clemmensen \& Jepsen, in press).

The Hagen Fjord Group, although still rather poorly known in detail, thus seems to record the establishment of a siliciclastic shelf that evolves into a carbonate platform; the demise of the carbonate platform coincides with the reappearance of siliciclastic sediments. The deep water deposits of the Rivieradal sandstone are probably in part equivalent to the lower part of the Hagen Fjord Group, although the precise relationship between these two successions remains to be fully established.

The planar unconformity between the Hagen Fjord Group and the overlying Lower Cambrian Portfjeld Formation marks a long hiatus around the ProterozoicCambrian boundary. During this period North Greenland was uplifted and peneplained before marine environments of the Franklinian Basin eventually transgressed the southern part of the shelf. The length of this hiatus is poorly constrained. Faunal evidence from the Portfjeld Formation suggests that the formation is of
Early Cambrian (early Atdabanian?) age (J. S. Peel, personal communication, 1990) corresponding to an absolute age of c. $560 \mathrm{Ma}$ (Harland et al., 1989). The top of the Morænesø Formation/Hagen Fjord Group succession probably lies within the Ediacaran (570-550 $\mathrm{Ma}$ ) which gives a hiatus of 10-30 Ma. However, in the northern part of the Franklinian shelf sedimentation started slightly earlier, since the Portfjeld Formation here is underlain by the Skagen Group of unknown, but probably earliest Cambrian age (Higgins et al., 1991).

\section{Late Proterozoic correlations in North Greenland}

The stratigraphic relationship between the geographically separated outcrops of the glacially influenced sediments of the Morænes $\varnothing$ Formation and the mainly shallow marine deposits of the Hagen Fjord Group is still uncertain, principally on account of the poor constraints on the age of the Hagen Fjord Group and its constituent formations.

The age of the Hagen Fjord Group can in part be assessed from acritarch assemblages from the upper part of the underlying Rivieradal sandstones at Centrum Sø; these suggest a general Sturtian to Vendian age (c. 800-570 Ma; G. Vidal in Hurst et al., 1985). However, the youngest strata of the group (Kap Holbæk Formation) contain Proterozoic acritarchs (Peel \& Vidal, 1988) and Skolithos-like burrows which together indicate an age not older than latest Proterozoic (late Vendian, Ediacaran; Crimes, 1987; Narbonne \& Myrow, 1988). Thus, the Morænes $\emptyset$ Formation diamictites, 
Late Proterozoic correlations in North and East Greenland

\begin{tabular}{ll|l|l|l|} 
North Greenland & A & East Greenland & North Greenland & East Greenland \\
\hline
\end{tabular}
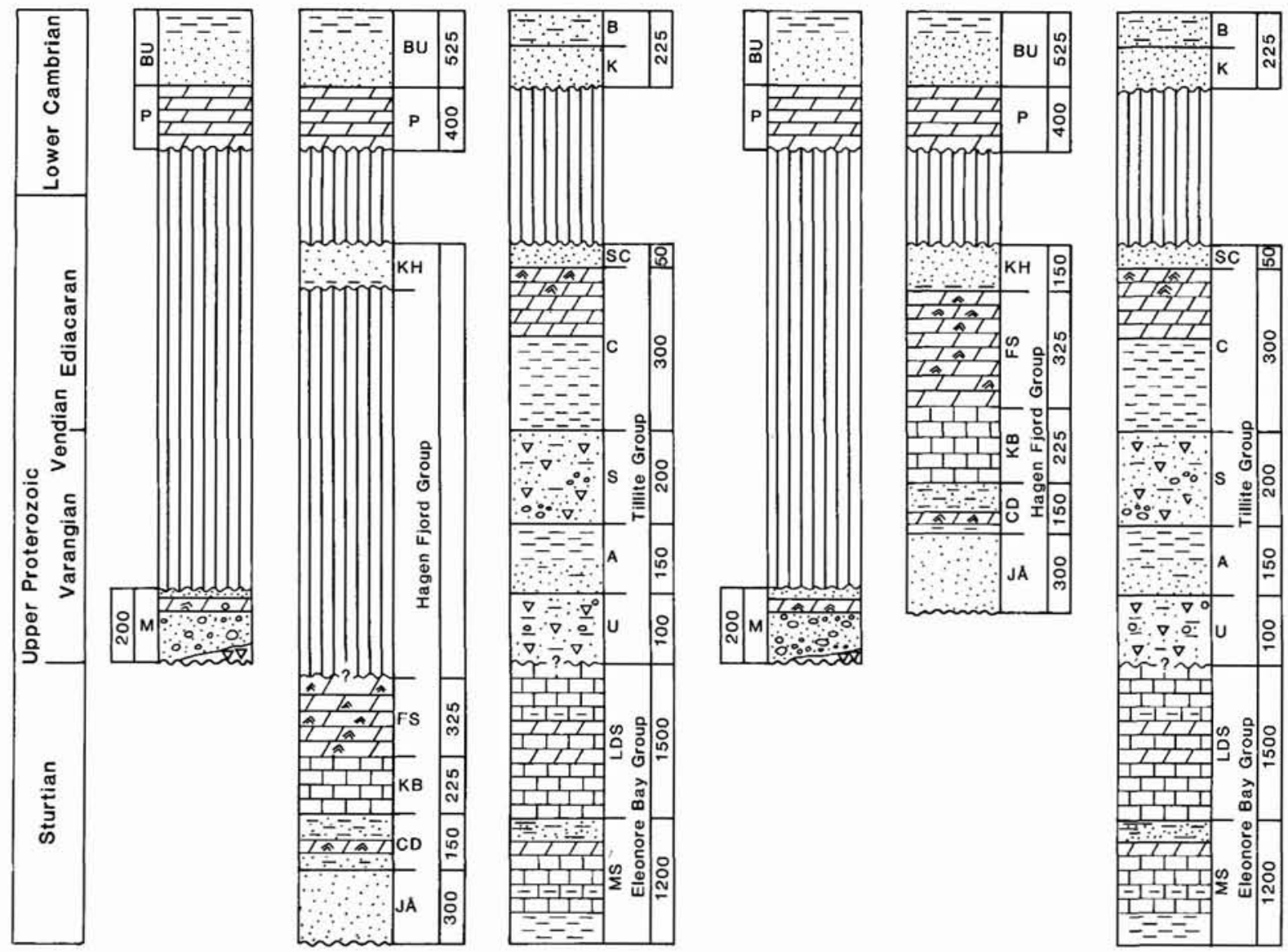

$\nabla_{\nabla}$ Tillite

$\because: 0$ Conglomerate Sandstone

$E=-$ Mudstone

ए Limestone

世 Dolomite

Stromatolite

Fig. 18. Possible Late Proterozoic correlations in North and East Greenland. Abbreviations denote formations unless otherwise mentioned. A, Arena; B, Bastion; BU, Buen; C, Canyon; CD, Campanuladal; FS, Fyns S $\varnothing ;$ J Å, Jyske Ås; K, Kløftelv; KB, Kap Bernhard; KH, Kap Holbæk; LDS, Limestone-Dolomite 'series'; M, Morænesø; MS, Multicoloured 'series'; P, Portfjeld; S, Storeelv; SC, Spiral Creek; U, Ulves $\emptyset$. Generalised thicknesses of individual units are indicated in metres.

if associated with the early Vendian (Varangian) glaciation, must be older than at least the Kap Holbæk Formation. As no signs of glacially related deposits have been found within the Hagen Fjord Group, the glacial diamictites of the Morænes $\varnothing$ Formation therefore are likely to be either older than the entire Hagen Fjord Group or to be associated with an as yet unrecognised hiatus within the group, resulting in two possible stratigraphic schemes for the Late Proterozic of North Greenland (Fig. 18).

Correlation A outlined in Fig. 18 suggests a hiatus between the Fyns Sø and Kap Holbæk Formations. This hiatus is mainly based upon an occurrence in the Morænes $\emptyset$ Formation of a stromatolitic dolomite clast very like the Fyns Sø Formation (J. D. Collinson, personal communication, 1990). Furthermore, similarities in the lithological evolution of the Eleonore Bay Group of East Greenland (cf. Henriksen \& Higgins, 1976) and the Hagen Fjord Group (apart from the Kap Holbæk Formation), which both show a change from siliciclastic to carbonate deposition, may suggest that these two groups of Late Proterozoic strata are partly coeval. The Eleonore Bay Group is overlain by the Vendian Tillite Group (Hambrey \& Spencer, 1987), and Hambrey \& 
Harland (1981) have suggested that the tillitic formations of Varangian age in the lower part of the Tillite Group correlate with the Morænes $\varnothing$ Formation in North Greenland. This correlation suggests that the main part of the Hagen Fjord Group is older than Varangian, and the acceptance of an Ediacaran age for the Kap Holbæk Formation thus necessitates an interpreted hiatus between the Fyns $\mathbf{\varnothing}$ and the Kap Holbæk Formations covering at least the Varangian Epoch (approximately $20 \mathrm{Ma}$; Harland et al., 1989).

The boundary between the Fyns S $ø$ and Kap Holbæk Formations has only been described from the type locality of the Fyns $S \varnothing$ Formation where it is a $1.5 \mathrm{~m}$ thick covered interval (Clemmensen \& Jepsen, in press). A hiatus at this level had been suggested earlier by Cowie (1961, p. 29 ff.), mainly based on observations by Fränkl (1955, p. 18 ff.) and from aerial reconnaissance by John Haller. Haller, however, apparently misidentified the carbonate-sandstone sequence now assigned to the Portfjeld and Buen Formations of Cambrian age, as the Proterozoic Fyns Sø and Kap Holbæk Formations.

The sub-Kap Holbæk Formation hiatus described by Fränkl (1955) was observed at a single locality within one of the nappe structures at Sæfaxi Elv in southern Kronprins Christian Land. At this locality a $1-5 \mathrm{~m}$ thick sandstone unit, which contains rafts of dolomite up to $1.5 \mathrm{~m}$ thick with 'karst-like' upper relief and a slightly erosive base, was correlated with the Kap Holbæk Formation (Fränkl, 1955, p. 18). The general stratigraphy at the locality at Sæfaxi Elv is very uncertain, however (see discussion in Peel \& Smith, 1988, p. 20), and the correlation was dismissed by Hurst et al. (1985). Fränkl $(1955$, p. 20$)$ himself noted the similarity of this sandstone to a quartzitic fissure-fill found at a similar stratigraphic level west of Sæfaxi Elv, and quartzitic cave and fissure-fills of Pliocene to Pleistocene age are known from many other localities in eastern North Greenland including Kap Holbæk (Loubière, 1987; J. S. Peel, personal communication, 1990).

Thus, an equally valid interpretation is that the Hagen Fjord Group as a whole postdates the tillites of the Morænes $\emptyset$ Formation (B in Fig. 18). The Hagen Fjord Group succession may therefore be correlated in terms of lithostratigraphy with the upper (i.e. post-diamictite) part of the Tillite Group of East Greenland. The change from predominantly siliciclastic to carbonate deposition seen in the Hagen Fjord Group is also observed within the Canyon Formation in the upper part of the Tillite Group (Fairchild \& Herrington, 1989; Fairchild, 1989). The basal part of the overlying Spiral Creek Formation (Fairchild \& Herrington, 1989) consists of tidal sand flat deposits comparable to the Kap Holbæk Formation (Fig. 18). If this correlation is correct, the incursion of possible marine environments in the upper part of the Morænes $ø$ Formation and the onlap of the Hagen Fjord Group may both be related to a glacio-eustatic transgression following the Varangian glaciation.

In a similar manner to the need for a better understanding of the tectono-stratigraphic relationship between the shelf sequence of the Hagen Fjord Group and the deep-water Rivieradal sandstones, the solution of this problem of correlation between the Morænes $\emptyset$ Formation and the Hagen Fjord Group must await further field work in eastern North Greenland.

Acknowledgements. Lars B. Clemmensen, John D. Collinson, Peter R. Dawes, Jon R. Ineson, Feiko Kalsbeck, John S. Peel and Finn Surlyk are thanked for critically reading the manuscript and for giving many valuable comments and suggestions for its improvement. Jette Halskov, Jakob Lautrup and Bente Thomas are thanked for technical assistance.

\section{References}

Adams, P. J. \& Cowie, J. W. 1953: A geological reconnaissance of the region around the inner part of Danmarks Fjord, Northeast Greenland. Meddr Grønland 111(7), 24 pp.

Caby, R. \& Bertrand-Sarfati, J. 1988: The Eleonore Bay Group (central East Greenland). In Winchester, J. A. (ed.) Later Proterozoic stratigraphy of the northern Atlantic regions, 212-236. Glasgow: Blackie \& Son Ltd.

Christie, R. L. \& Dawes, P. R. in press: Geographic and geologic exploration. In Trettin, H. P. (ed.) Innuitian Orogen and Arctic Platform; Canada and Greenland. Geology of Canada 3. Ottawa: Geol. Surv. Canada (also The geology of North America E. Boulder, Colorado: Geol. Soc. America).

Christie, R. L. \& Ineson, J. R. 1979: Precambrian-Silurian geology of the G. B. Schley Fjord region, eastern Peary Land, North Greenland. Rapp. Grønlands geol. Unders. 88, 63-71.

Clemmensen, L. B. 1979: Notes on the palacogeographical setting of the Eocambrian tillite-bearing sequence of southern Peary Land, North Greenland. Rapp. Grønlands geol. Unders. 88, 15-22.

Clemmensen, L. B. 1981: Late Precambrian tilloids of Peary Land, North Greenland. In Hambrey, M. J. \& Harland, W. B. (ed.) Earth's pre-Pleistocene glacial record, 782-786. Cambridge: Cambridge University Press.

Clemmensen, L. B. \& Jepsen, H. F. in press: Lithostratigraphy and geological setting of Upper Proterozoic shelf deposits, Hagen Fjord Group, eastern North Greenland. Rapp. Grønlands geol. Unders.

Collinson, J. D. 1980: Stratigraphy of the Independence Fjord Group (Proterozoic) of eastern North Greenland. Rapp. Grønlands geol. Unders. 99, 7-23.

Collinson, J. D. 1983: Sedimentology of unconformities within a fluvio-lacustrine sequence; Middle Proterozoic of eastern North Greenland. Sedimentary Geol. 34 145-166. 
Collinson, J. D., Bevins, R. E. \& Clemmensen, L. B. 1989: Post-glacial mass flow and associated deposits preserved in palaeovalleys: the Late Precambrian Morænes $\emptyset$ Formation, North Greenland. Meddr Gronland Geosci. 21, 26 pp.

Cowie, J. W. 1961: Contributions to the geology of North Greenland. Meddr Grønland 164(3), 47 pp.

Crimes, T. P. 1987: Trace fossils and correlation of late Precambrian and early Cambrian strata. Geol. Mag. 124, 97119.

Dawes, P. R. 1971: The North Greenland fold belt and environs. Bull. geol. Soc. Denmark 20, 197-239.

Dawes, P. R. 1976: Precambrian to Tertiary of northern Greenland. In Escher, A. \& Watt, W. S. (ed.) Geology of Greenland, 248-303. Copenhagen: Geol. Surv. Greenland.

Dawes, P. R. 1988: Etah meta-igneous complex and the Wulff structure: Proterozoic magmatism and deformation in Inglefield Land, North-West Greenland. Rapp. Grønlands geol. Unders. 139, 24 pp.

Dawes, P. R. \& Christic, R. L. 1982: History of exploration and geology in the Nares Strait region. In Dawes, P. R. \& Kerr, J. W. (ed.) Nares Strait and the drift of Greenland: a conflict in plate tectonics. Meddr Gronland Geosci. 8, 19-36.

Dawes, P. R. \& Rex, D. C. 1986: Proterozoic basaltic magmatic periods in North-West Greenland: evidence from $\mathrm{K} / \mathrm{Ar}$ ages. Rapp. Grønlands geol. Unders. 130, 24-31.

Dawes, P. R. \& Vidal, G. 1985: Proterozoic age of the Thule Group: new evidence from microfossils. Rapp. Grønlands geol. Unders. 125, 22-28.

Dawes, P. R., Rex, D. C. \& Jepsen, H. F. 1973: K/Ar whole rock ages of dolerites from the Thule district, western North Greenland. Rapp. Gronlands geol. Unders. 55, 61-66.

Dawes, P. R., Frisch, T. \& Christie, R. L. 1982: The Proterozoic Thule Basin of Greenland and Ellesmere Island: importance to the Nares Strait debate. In Dawes, P. R. \& Kerr, J. W. (ed.) Nares Strait and the drift of Greenland: a conflict in plate tectonics. Meddr Grønland Geosci. 8, 89-104.

Dawes, P. R., Larsen, O. \& Kalsbeek, F., 1988: Archean and Proterozoic crust in North-West Greenland: evidence from Rb-Sr whole-rock age determinations. Can. J. Earth Sci. 25, 1365-1373.

Donaldson, J. A. 1976: Paleoecology of Conophyton and associated stromatolites in the Precambrian Dismal Lakes and Rae Groups, Canada. In Walter, M. R. (ed.) Stromatolites, 523-534. Amsterdam: Elscvier.

Ellitsgaard-Rasmussen, K. 1950: Preliminary report on the geological field work carried out by the Danish Peary Land Expedition in the year 1949-50. Meddr dansk geol. Foren. 11, 589-595.

Fahrig, W. F., Christie, K. W. \& Jones, D. L. 1981: Paleomagnetism of the Bylot basins: evidence for Mackenzie continental tensional tectonics. In Campbell, F. H. A. (ed.) Proterozoic basins of Canada. Pap. geol. Surv. Can. 81-10, 303-312.

Fairchild, I. J. 1989: Dolomitic stromatolite-bearing units with storm deposits from the Vendian of East Greenland and Scotland: a case of facies equivalence. In Gayer, R. A. (ed.) The Caledonide geology of Scandinavia, 275-283. London: Graham \& Trotman.
Fairchild, I. J. \& Herrington, P. M. 1989: A tempestite-stromatolite-evaporite association (late Vendian, East Greenland): a shoreface-lagoon model. Precamb. Res. 43, 101-127.

Føyn, S. \& Siedlecki, S. 1980: Glacial stadials and interstadials of the Late Precambrian Smallfjord Tillite on Laksefjordvidda, Finnmark, North Norway. Norges geol. Unders. 358, $31-45$.

Fränkl, E. 1954: Vorläufige Mitteilung über die Geologie von Kronprins Christians Land (NE-Grönland). Meddr Grønland 116(2), $85 \mathrm{pp}$.

Fränkl, E. 1955: Weitere Beiträge zur Geologie von Kronprins Christians Land (NE-Grönland). Meddr Grønland 103(7), $35 \mathrm{pp}$.

Friderichsen, J. D., Holdsworth, R. E., Jepsen, H. F. \& Strachan, R. A. 1990: Caledonian and pre-Caledonian geology of Dronning Louise Land, North-East Greenland. Rapp. Grønlands geol. Unders. 148, 133-141.

Grotzinger, J. P. 1989: Facies and evolution of Precambrian carbonate depositional systems: emergence of the modern platform archetype. In Crevello, P. D., Wilson, J. L., Sarg, J. F. \& Read, J. F. (ed.) Controls on carbonate platform and basin development. Spec. Publ. Soc. Econ. Pal. Min. 44, 79-106.

Haller, J. 1971: Geology of the East Greenland Caledonides, 413 pp. London: Interscience Publ.

Haller, J. 1983: Geological map of Northeast Greenland $75^{\circ}-82^{\circ}$ N. lat. 1:1.000.000 Meddr Grønland 200(5), 22 pp.

Hambrey, M. J. 1988: Late Proterozoic stratigraphy of the Barents Shelf. In Harland, W. B. \& Dowdeswell, E. K. (ed.) Geological evolution of the Barents Shelf region, 49-72. London: Graham \& Trotman.

Hambrey, M. J. \& Harland, W. B. 1981: Earth's pre-Pleistocene glacial record, 1004 pp. Cambridge: Cambridge University Press.

Hambrey, M. J. \& Spencer, A. M. 1987: Late Precambrian glaciation of central East Greenland. Meddr Grønland Geosci. 19, 50 pp.

Hansen, B. T., Kalsbeek, F. \& Holm, P. M. 1987: Archaean age and Proterozoic metamorphic overprinting of the crystalline basement at Victoria Fjord, North Greenland, Rapp. Grønlands geol. Unders. 133, 159-168.

Harland, W. B., Armstrong, R. L., Cox, A. V., Craig, L. E., Smith, A. G. \& Smith, D. G. 1989: A geologic time scale, 263 pp. Cambridge: Cambridge University Press.

Henriksen, N. (compiler) 1989: Geological map of Greenland, Sheet 7, Nyeboe Land, 1:500.000. Copenhagen: Geol. Surv. Greenland.

Henriksen, N. \& Higgins, A. K. 1976: East Greenland Caledonian fold belt. In Escher, A. \& Watt, W. S. (ed.) Geology of Greenland, 182-246. Copenhagen: Geol. Surv. Greenland.

Henriksen, N. \& Jepsen, H. F. 1970: K/Ar age determinations on dolerites from southern Peary Land, North Greenland. Rapp. Grønlands geol. Unders. 35, 55-58.

Higgins, A. K., Ineson, J. R., Peel, J. S., Surlyk, F. \& Sønderholm, M. 1991: Lower Palaeozoic Franklinian Basin of North Greenland. Bull. Grønlands geol. Unders. 160 (this volume). 
Hoffman, P. 1976: Environmental diversity of Middle Precambrian stromatolites. In Walter, M. R. (ed.) Stromatolites, 599-611. Amsterdam: Elsevier.

Hurst, J. M. \& McKerrow, W. S. 1981a: The Caledonian nappes of Kronprins Christian Land, eastern North Greenland. Rapp. Grønlands geol. Unders. 106, 15-19.

Hurst, J. M. \& McKerrow, W. S. 1981b: The Caledonian nappes of eastern North Greenland. Nature 290, 772-774.

Hurst, J. M. \& McKerrow, W. S. 1985: Origin of the Caledonian nappes of eastern North Greenland. In Gee, D. G. \& Sturt, B. A. (ed.) The Caledonide Orogen: Scandinavia and related areas, 1065-1069. London: Wiley \& Sons.

Hurst, J. M., Jepsen, H. F., Kalsbeek, F., McKerrow, W. S. \& Peel, J. S. 1985: The geology of the northern extremity of the East Greenland Caledonides. In Gee, D. G. \& Sturt, B. A. (ed.) The Caledonide Orogen: Scandinavia and related areas, 1047-1063. London: Wiley \& Sons.

Jackson, G. D. \& Iannelli, T. R. 1981: Rift-related cyclic sedimentation in the Neohelikian Borden Basin, northern Baffin Island. In Campbell, F. H. A. (ed.) Proterozoic basins of Canada. Pap. geol. Surv. Can. 81-10, 269-302.

Jepsen, H. F. 1971: The Precambrian, Eocambrian and Early Palaeozoic stratigraphy of the Jørgen Brønlund Fjord area, Peary Land, North Greenland. Meddr Grønland 192(2), 42 pp.

Jepsen, H. F. \& Kalsbeek, F. 1979: Igneous rocks in the Proterozoic platform of eastern North Greenland. Rapp. Grønlands geol. Unders. 88, 11-14.

Jepsen, H. F. \& Kalsbeek, F. 1985: Evidence for non-existence of a Carolinidian fold belt in eastern North Greenland. In Gee, D. G. \& Sturt, B. A. (ed.) The Caledonide Orogen; Scandinavia and related areas, 1071-1076. London: Wiley \& Sons.

Jepsen, H. F., Kalsbeek, F. \& Suthren, R. J. 1980: The ZigZag Dal Basalt Formation, North Greenland. Rapp. Grønlands geol. Unders. 99, 25-32.

Kalsbeck, F. \& Jepsen, H. F. 1983: The Midsommersø Dolerites and associated intrusions in the Proterozoic platform of eastern North Greenland - a study of the interaction between intrusive basic magma and sialic crust. J. Petrol. 24, 605-634.

Kalsbeek, F. \& Jepsen, H. F. 1984: The late Proterozoic ZigZag Dal Basalt Formation of eastern North Greenland. J. Petrol. 25, 644-664.

Koch, L. 1920: Stratigraphy of Northwest Greenland. Meddr dansk geol. Foren. 5(17), 78 pp.

Koch, L. 1925: The geology of North Greenland. Am. J. Sci. (5), 9, 271-285.

Koch, L. 1929: Stratigraphy of Greenland. Meddr Grønland 73(2), 2, 205-320.

Koch, L. 1933: The geology of Inglefield Land. Meddr Grønland 73(1),2, $38 \mathrm{pp}$.

Larsen, O. \& Graff-Petersen, P. 1980: Sr-isotopic studies and mineral composition of the Hagen Bræ Member in the Proterozoic clastic sediments at Hagen Bræ, eastern North Greenland. Rapp. Gronlands geol. Unders. 99, 111-118.
Loubière, J.-F. 1987: Observations preliminaires sur les cavités de la region du Lac Centrum (Nord-Est Groenland). Karstologia 9, 7-16.

Marcussen, C. \& Abrahamsen, N. 1983: Palaeomagnetism of the Proterozoic Zig-Zag Dal Basalt and the Midsommers $\emptyset$ Dolerites, eastern North Greenland. Geophys. J. R. astr. Soc. 73, 367-387.

Narbonne, G. M. \& Myrow, P. 1988: Trace fossil biostratigraphy in the Precambrian-Cambrian boundary interval. Bull. N. Y. State Mus. 463, 72-76.

Peacock, J. D. 1956: The geology of Dronning Louise Land, N.E. Greenland. Meddr Grønland 137(7), 38 pp.

Peel, J. S. \& Smith, M. P. 1988: The Wandel Valley Formation (Early-Middle Ordovician) of North Greenland and its correlatives. Rapp. Gronlands geol. Unders. 137, 61-92.

Peel, J. S. \& Vidal, G. 1988: Acritarchs from the Kap Holbæk Formation, North Greenland. Rapp. Gronlands geol. Unders. 137, 42 only.

Peel, J. S., Dawes, P. R., Collinson, J. D. \& Christic, R. L. 1982: Proterozoic - basal Cambrian stratigraphy across Nares Strait: correlation between Inglefield Land and Bache Peninsula. In Dawes, P. R. \& Kerr, J. W. (ed.) Nares Strait and the drift of Greenland: a conflict in plate tectonics. Meddr Grønland Geosci. 8, 105-115.

Read, J. F. 1982: Carbonate platforms of passive (extensional) continental margins: types, characteristics and evolution. Tectonophysics 81, 195-212.

Sønderholm, M. \& Tirsgaard, H. 1990: Sedimentological investigations of the Multicoloured 'series' (Eleonore Bay Group, Late Precambrian) in the Scoresby Land - Andrée Land region, central East Greenland. Rapp. Gronlands geol. Unders. 148, 115-122.

Sønderholm, M., Collinson, J. D. \& Tirsgaard, H. 1989: Stratigraphic and sedimentological studies of the Eleonore Bay Group (Precambrian) between $73^{\circ} 30^{\prime}$ and $76^{\circ} \mathrm{N}$ in East Greenland. Rapp. Grønlands geol. Unders. 145, 97-102.

Stewart, W. D. 1987: Late Proterozoic to Early Tertiary stratigraphy of Somerset Island and northern Boothia Peninsula, District of Franklin, N.W.T. Pap. geol. Surv. Can. 83-26, 43 pp.

Trettin, H. P. 1987: Pearya: a composite terrane with Caledonian affinities in northern Ellesmere Island. Can. J. Earth Sci. 24, 224-245.

Troelsen, J. C. 1949: Contributions to the geology of the area round Jørgen Brønlunds Fjord, Peary Land, North Greenland. Meddr Grønland 149(2), 29 pp.

Troelsen, J. C. 1950: Contributions to the geology of Northwest Greenland, Ellesmere Island and Axel Heiberg Island. Meddr Grønland 149(7), 86 pp.

Troelsen, J. C. 1956: Groenland - Greenland. Lexique stratigraphique international. Vol. 1. Europe, fasc. Ia, $116 \mathrm{pp}$. Paris: C. N. R. S.

Young, G. M. 1981: The Amundsen Embayment, Northwest Territories; relevance to the Upper Proterozoic cvolution of North America. In Campbell, F. H. A. (ed.) Proterozoic basins of Canada. Pap. geol. Surv. Can. 81-10, 203-218. 

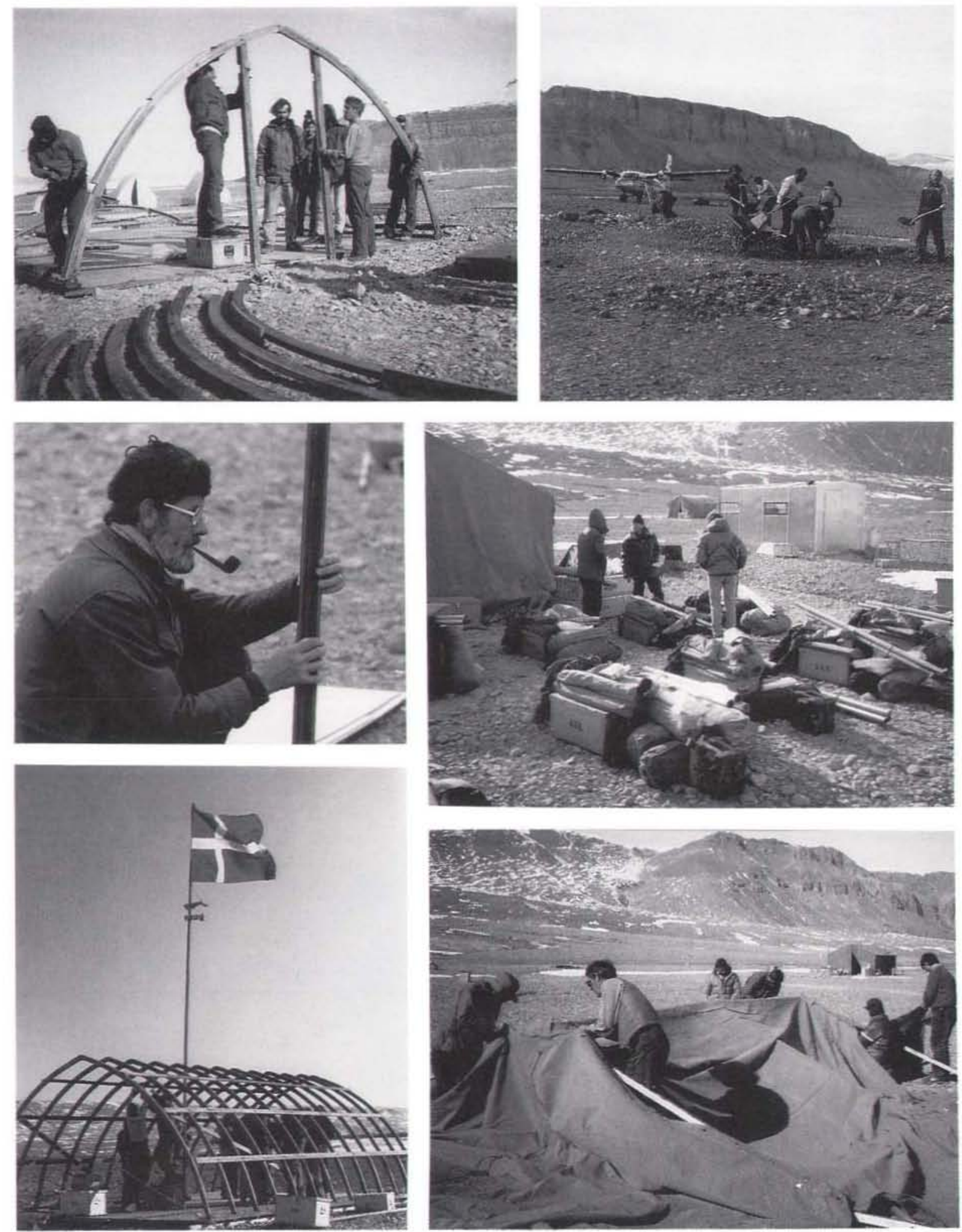

The North Greenland Project: establishing base camps in Peary Land and Warming Land. 